\title{
Gold-acetonyl complexes: from side-products to valuable
} synthons

\author{
Danila Gasperini, ${ }^{a}$ Alba Collado, ${ }^{a}$ Adrián Goméz-Suárez, ${ }^{a}$ David B. Cordes, ${ }^{a}$ Alexandra M. Z. Slawin ${ }^{a}$ and
} Steven P. Nolan ${ }^{a, b *}$

Abstract: A novel synthetic strategy was devised leading to the formation of complexes such as $\left[\mathrm{Au}(\mathrm{IPr})\left(\mathrm{CH}_{2} \mathrm{COCH}_{3}\right)\right]$. The approach capitalizes on the formation of a decomposition product observed in the course of the synthesis of $[\mathrm{Au}(\mathrm{IPr})(\mathrm{Cl})]$. A library of gold acetonyl complexes bearing the most common $\mathrm{N}$-heterocyclic carbene (NHC) ligands has been synthesized. These acetonyl complexes are good synthons for the preparation of numerous organogold complexes. Moreover, they have proven to be precatalysts in common gold(I)-catalyzed reactions.

\section{Introduction}

The interest in gold chemistry has grown exponentially in the last decades. ${ }^{[1]}$ Gold species have been found to be highly active catalysts for both homogeneous and heterogeneous transformations. ${ }^{[2]}$ Moreover, organogold complexes present luminescent and biological properties, which make them attractive for the synthesis of new materials and for biomedical applications. ${ }^{[3]}$

Initially, the use of simple gold salts as catalysts, such as $\mathrm{AuCl}, \mathrm{AuCl}_{3}$ or $\mathrm{NaAuCl}_{4}$, was ubiquitous in gold catalysis. More recently, particular attention has been focused on the development of well-defined $\mathrm{Au}(\mathrm{I})$ and $\mathrm{Au}(\mathrm{III})$ complexes bearing ancillary ligands in order to examine whether or not enhanced catalytic activity could be achieved. ${ }^{[1 a, 2 a, 4]}$

$\mathrm{N}$-heterocyclic carbene (NHC) species have appeared as excellent ligands for the synthesis of a wide range of organometallic complexes. ${ }^{[5]}$ Their strong $\sigma$-donating ability and steric hindrance allow for strong metal-ligand bonds and prevent complex decomposition. ${ }^{[6]}$ The use of $\mathrm{NHC}$ ligands in gold chemistry has allowed for the synthesis of a plethora of organogold complexes. ${ }^{[7]}$ Indeed, highly unstable species have been isolated due to the unique properties of such ligands, e.g. the first $\mathrm{Au}(\mathrm{I})$-tert-butoxide ${ }^{[8]}, \mathrm{Au}(\mathrm{I})$-fluoride ${ }^{[8]}$ and $\mathrm{Au}(\mathrm{I})$-hydride ${ }^{[9]}$ species reported by the group of Sadighi, as well as the Au(I)hydroxide ${ }^{[10]}$ and $\mathrm{Au}(\mathrm{I})$-alkylperoxo ${ }^{[11]}$ complexes synthesized by Nolan and co-workers.

[a] Danila Gasperini, Dr. Alba Collado, Dr. Adrián Goméz-Suárez, Dr. David B. Cordes, Prof. Dr. Alexandra M. Z. Slawin and Prof. Dr. Steven P. Nolan

EaStCHEM, School of chemistry, University of St. Andrews,

Purdie Building, North Haugh, St. Andrews,

Fife KY16 9ST (UK)

sn17@st-andrews.ac.uk

[b] Prof. Dr. Steven P. Nolan

Chemistry Department, College of Science, King Saud University, P.O. Box 2455, Riyadh 11451 (Saudi Arabia)

Supporting information for this article is available on the WWW under http://dx.doi.org/10.1002....
Among these complexes, $[\mathrm{Au}(\mathrm{NHC})(\mathrm{Cl})]$ compounds have been recognized as valuable precursors for several organogold complexes. ${ }^{[7 c]}$ An improved protocol for their synthesis has recently been developed. ${ }^{[12]}$ This straightforward synthetic procedure allows for the preparation of $[\mathrm{Au}(\mathrm{NHC})(\mathrm{Cl})]$ complexes by reacting the corresponding imidazol(idin)ium salt $(\mathrm{NHC} \cdot \mathrm{HCl})$ with $\left[\mathrm{Au}\left(\mathrm{SMe}_{2}\right)(\mathrm{Cl})\right]$ in the presence of a weak base, such as $\mathrm{K}_{2} \mathrm{CO}_{3}$, in acetone at $60^{\circ} \mathrm{C}$ (eq. a, Scheme 1).

The reaction time was found to depend on the nature of the $\mathrm{NHC} \cdot \mathrm{HCl}$ salt. While $[\mathrm{Au}(\mathrm{IPr})(\mathrm{Cl})]^{[13]}(\mathbf{1 a})$ and $[\mathrm{Au}(\mathrm{IMes})(\mathrm{Cl})]^{[14]}$ (1b) were obtained in $1 \mathrm{~h}$ and $3 \mathrm{~h}$ respectively, the synthesis of $[\mathrm{Au}(\mathrm{SIPr})(\mathrm{Cl})]^{[15]}(\mathbf{1 c})$ or $[\mathrm{Au}(\mathrm{SIMes})(\mathrm{Cl})]^{[16]}(\mathbf{1 d})$ required $24 \mathrm{~h}$, under the same reaction conditions.

In an effort to reduce the reaction time for the synthesis of the gold(I)-chloride complexes bearing a saturated NHC ligand(1c), a large excess of $\mathrm{K}_{2} \mathrm{CO}_{3}$ (6 equiv.) was added to the reaction mixture. To our surprise, a mixture of complexes was obtained. The expected $[\mathrm{Au}(\mathrm{SIPr})(\mathrm{Cl})]($ 1c) and a new Au-SIPr derivative were obtained in a 1.3:1 ratio. ${ }^{1} \mathrm{H}$ and ${ }^{13} \mathrm{C}\left\{{ }^{1} \mathrm{H}\right\}$ NMR analysis of the mixture allowed the characterization of the desired $\mathrm{Au}-\mathrm{Cl}$ complex and of a new species identified as the acetonyl complex [Au(SIPr) $\left.\left(\mathrm{CH}_{2} \mathrm{COCH}_{3}\right)\right]$ (2c) (eq. b, Scheme 1).
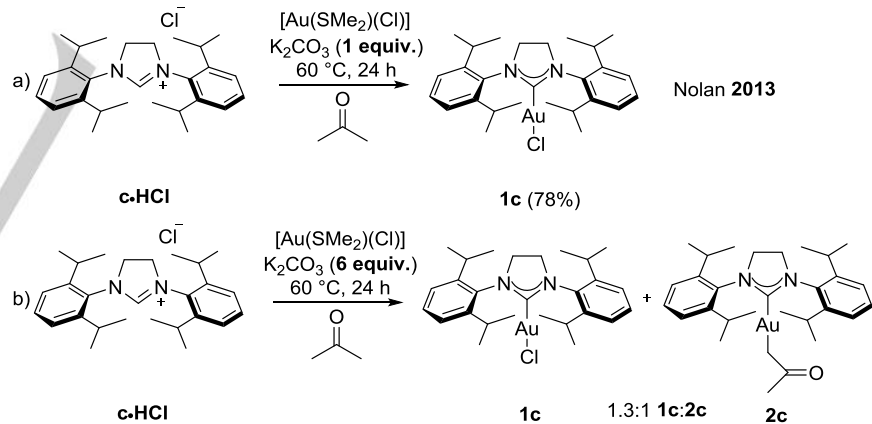

Scheme 1. Formation of Au-chloride complex 1c and Au-acetonyl complex 2c.

Intrigued by the formation of this acetonyl complex, we decided to explore whether this derivative was also formed using the unsaturated and commercially available $\mathrm{IPr} \cdot \mathrm{HCl}$ salt $(\mathbf{a} \cdot \mathbf{H C l})$. Therefore, a mixture of $\mathrm{IPr} \cdot \mathrm{HCl}$ and $\left[\mathrm{Au}\left(\mathrm{SMe}_{2}\right)(\mathrm{Cl})\right]$ in equimolar amounts was stirred in acetone at $60{ }^{\circ} \mathrm{C}$ in the presence of 6 equivalents of $\mathrm{K}_{2} \mathrm{CO}_{3}$. After $48 \mathrm{~h}$, full conversion to $\left[\mathrm{Au}(\mathrm{IPr})\left(\mathrm{CH}_{2} \mathrm{COCH}_{3}\right)\right](\mathbf{2 a})$ was obtained and the product was isolated in $80 \%$ yield (Scheme 2 ). 


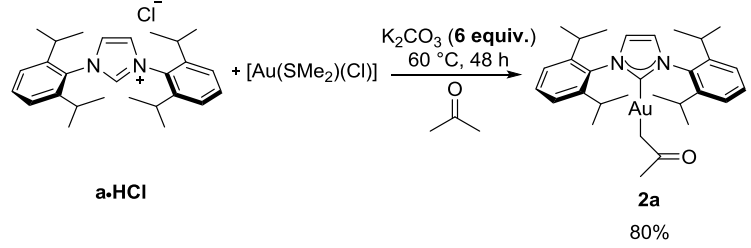

Scheme 2. Conversion of $\mathbf{a} \cdot \mathbf{H C l}$ and $\left[\mathrm{Au}\left(\mathrm{SMe}_{2}\right)(\mathrm{Cl})\right]$ into $\mathbf{2 a}$

These new species, bearing an acetonyl fragment, are members of the family of organogold-enolates. The term "enolate" usually refers to the tautomeric structures of a ketone; this structure reacts with a metal unit forming enol-M bonds (I), $\eta^{3}$-oxoallyl-M (II) and 2-oxoalkyl-M complexes (III) (Figure 1). ${ }^{[17]}$
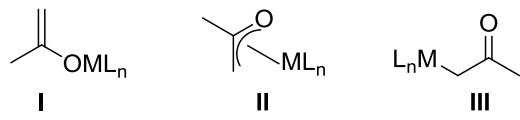

Figure 1. Different types of Metal-enolate bonding.

Type III C-enolates or ketonyl complexes, ${ }^{[18]}$ are interesting organometallic compounds, proposed to be involved as shortlived intermediates in organic transformations. ${ }^{[19]} \mathrm{A}$ range of synthetic methodologies have been used to form these $M$ ketonyl derivatives, ${ }^{[18,20]}$ e.g. oxidative addition to organometallic compounds of $\alpha$-halogen carbonyl compounds ${ }^{[21]}$ or epoxides, ${ }^{[22]}$ transmetallation reactions promoted by $\mathrm{Hg}$ salts [18, 23] or reactions of Main-group enolates with electrophilic metal centers. ${ }^{[19 a, 24]}$ Other methodologies involve reactions of carbonyl compounds with metal-hydroxide ${ }^{[25]}$ or metal-chloride complexes in the presence of bases such as $\mathrm{Ag}_{2} \mathrm{O}, \mathrm{KOH}$ and $\mathrm{NaOH} .{ }^{[20 \mathrm{c}, 26]}$

Following these procedures, various $\mathrm{M}$-ketonyl species have been isolated using late-transition metals, such as $\mathrm{Rh}, \mathrm{Ni}, \mathrm{Pt}, \mathrm{Pd}$ and $\mathrm{Au} .{ }^{[18,20 \mathrm{c}, 20 \mathrm{e}, 20 \mathrm{~g}, 27]}$ With regard to the latter, in 1989 Vicente reported the synthesis of $\mathrm{Au}(\mathrm{III})$-ketonyl complexes by $\mathrm{C}-\mathrm{H}$ bond activation of acetone promoted by the ancillary bidentate ligand bound to the metal center. ${ }^{[28]}$ Cinellu reported a similar structure of $\mathrm{Au}(\mathrm{III})$-acetonyl complex bearing a $\mathrm{C}, \mathrm{N}$-cyclometallated ligand in 1996. ${ }^{[29]}$ Similar Au(III)-ketonyl complexes, bearing a chelating ligand, 2-phenylpyridine (ppy), were reported by Fan in 2004. ${ }^{[30]}$ Furthermore, Ito synthesized and fully characterized stable $\mathrm{Au}(\mathrm{I})\left(\mathrm{PPh}_{3}\right)$-ketonyl and -homoketonyl complexes by adding sylilated vinyl ethers or epoxides to $\mathrm{Au}(\mathrm{I})\left(\mathrm{PPh}_{3}\right)$-chloride, in the presence of cesium fluoride. ${ }^{[31]}$ Crystal structures of $\mathrm{Au}(\mathrm{I})$ acetonyl phosphine complexes and analogues were reported by the groups of Kuzmina and Laguna (Figure 2).$^{[19 d, 32]}$

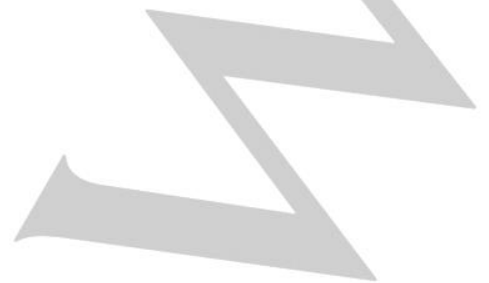

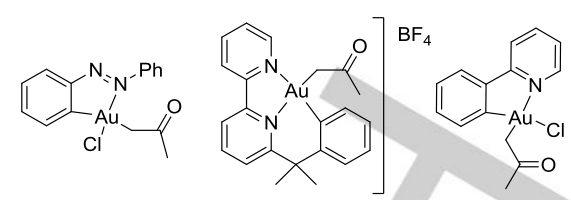

Vicente $1989 \quad$ Cinellu $1996 \quad$ Fan 2004

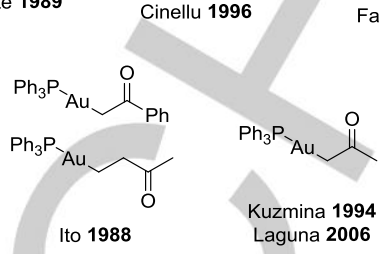

Figure 2. Some examples of reported $\mathrm{Au}(\mathrm{I})$ and $\mathrm{Au}(\mathrm{III})$-ketonyl complexes

To the best of our knowledge, no examples of Au-NHC ketonyl compounds have been reported to date. Herein, we report the serendipitous discovery of the first gold(I)-NHC acetonyl complexes and the study of their stoichiometric and catalytic reactivity.

\section{Results and Discussion}

\section{Characterization of $[\mathrm{Au}(\mathrm{IPr})($ acetonyl)] (2a)}

As previously stated, $\mathbf{2 a}$ was obtained as a single species, when mixing $\mathrm{IPr} \cdot \mathrm{HCl}(\mathbf{a} \cdot \mathrm{HCl}),\left[\mathrm{Au}\left(\mathrm{SMe}_{2}\right)(\mathrm{Cl})\right]$ and $\mathrm{K}_{2} \mathrm{CO}_{3}$ (6 equiv.) in acetone at $60{ }^{\circ} \mathrm{C}$ for $48 \mathrm{~h}$ (Scheme 2). The new air- and moisture-stable derivative was isolated as a white solid in $80 \%$ yield. Complex $2 \mathbf{a}$ was fully characterized by NMR and IR spectroscopies, elemental analysis and $\mathrm{X}$-ray diffraction studies. The ${ }^{1} \mathrm{H}$ NMR spectrum in $\mathrm{CDCl}_{3}$, indicated the presence of a functionalized acetone moiety: a singlet at $2.06 \mathrm{ppm}$ that was assigned to the $-\mathrm{CH}_{2}$ group, and a singlet at $1.54 \mathrm{ppm}$ corresponding to the $-\mathrm{CH}_{3}$ moiety. The ${ }^{13} \mathrm{C}\left\{{ }^{1} \mathrm{H}\right\}$ NMR spectrum showed a signal at $212.13 \mathrm{ppm}$ that was assigned to the carbonyl group. This signal is shifted downfield with respect to free acetone (207.07 ppm). The FTIR (ATR) spectrum of $\mathbf{2 a}$ showed a strong absorption band at $1643 \mathrm{~cm}^{-1}$, corresponding to the stretching frequency of the carbonyl group ( $v C O)$, in agreement with previously reported Au-acetonyl compounds. ${ }^{[28 c]}$ Suitable crystals for X-ray diffraction analysis were grown by slow diffusion of pentane into a saturated solution of $\mathbf{2 a}$ in $\mathrm{DCM}^{[33]}$ The crystallographic representation of $\mathbf{2 a}$ is presented in Figure 3. The structure of $\mathbf{2 a}$ displays the usual linear geometry for $\mathrm{Au}(\mathrm{I})$ complexes, with a $\mathrm{C}_{\text {carbene }}-\mathrm{Au}-\mathrm{CH}_{2}$ angle of $175.7(3)^{\circ} .^{[31 a]}$ The Au- $\mathrm{C}_{\text {carbene }}$ distance of $2.024(7) \AA$ lies in the typical range for gold(I)-NHC species. ${ }^{[7 \mathrm{c}, 31 \mathrm{a}]}$ Other relevant distances are $\mathrm{Au}-\mathrm{CH}_{2}$ of 2.091(9) $\AA, \mathrm{CH}_{2}-\mathrm{CO}, 1.456(12) \AA$, and $\mathrm{C}=\mathrm{O}, 1.230(11) \AA$, which are in agreement with previously reported Au-acetonyl complexes. ${ }^{\text {[7c, } 30-31]}$ 


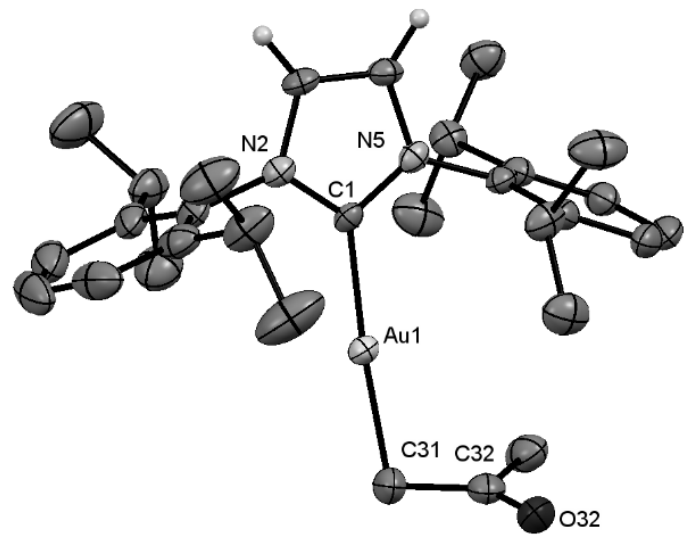

Figure 3. Thermal ellipsoid representation of 2a showing $50 \%$ probability. Most of the $\mathrm{H}$ atoms were omitted for clarity. Selected bond angles (deg) and lengths $(\AA)$ : C1-Au-C31 175.7(3) ${ }^{\circ}$; Au-C1 2.024(7) $\AA$; Au-C31 of 2.091(9) $\AA$; C31-32 1.456(12) A, C32-O32 of $1.230(11) \AA$.

\section{Synthetic Methodologies for the Preparation of [Au(IPr)(acetonyl)] 2a}

Once 2a was fully characterized, several synthetic approaches leading to its formation were investigated, including the use of various bases. The addition of $\mathrm{KOH}$ ( 6 equiv.) led to the isolation of $2 a$ in $47 \%$ isolated yield after $48 \mathrm{~h}$ (route $\mathrm{A}$, Scheme 3 ), while the addition of $\mathrm{NEt}_{3}$ (6 equiv.) led to recover the chloride derivative 1a.

Once it was established that $\mathrm{K}_{2} \mathrm{CO}_{3}$ was the best base to promote the transformation, we studied the reaction using the well-defined $[\mathrm{Au}(\mathrm{IPr})(\mathrm{Cl})](\mathbf{1 a})$ rather than $\mathbf{a} \cdot \mathbf{H C l}$. Treatment of $\mathbf{1 a}$ with 6 equiv. of $\mathrm{K}_{2} \mathrm{CO}_{3}$ in acetone at $60^{\circ} \mathrm{C}$ gave full conversion to the acetonyl complex after $24 \mathrm{~h}$ (route B, Scheme 3). 2a was isolated in $84 \%$ yield and $81 \%$ overall yield from $\left[\mathrm{Au}\left(\mathrm{SMe}_{2}\right)(\mathrm{Cl})\right]$ used in the preparation of $[\mathrm{Au}(\mathrm{IPr})(\mathrm{Cl})]^{[12]}$

Finally, the possibility of forming acetonyl complexes without an external base was investigated. Gratifyingly, [Au(IPr)(acetonyl)] was obtained in $90 \%$ yield using $[\mathrm{Au}(\mathrm{IPr})(\mathrm{OH})](\mathbf{3 a})$ by simply stirring $3 a$ in acetone at room temperature for $4 \mathrm{~h}$. This represents an $86 \%$ overall yield (based on the initial $\left[\mathrm{Au}\left(\mathrm{SMe}_{2}\right)(\mathrm{Cl})\right]$ synthon) taking into account the preparation of $[\mathrm{Au}(\mathrm{IPr})(\mathrm{OH})]$ (route $\mathbf{C}$, Scheme 3). ${ }^{[10,34]}$ It should be noted that all reactions were carried out under air and made use of technical grade solvents.

The formation of the acetonyl complex can be explained as follows (Scheme 4): in route $\mathbf{A},[\mathrm{Au}(\mathrm{IPr})(\mathrm{Cl})]$ is initially formed, as observed by ${ }^{1} \mathrm{H}$ NMR spectroscopy. From this point, route $\mathbf{A}$ and B proceed via the same mechanism. The large excess of base $\left(\mathrm{K}_{2} \mathrm{CO}_{3}\right)$ would promote deprotonation of acetone generating the corresponding tautomer, that would then react with the soft electrophilic metal center in 1a, affording $\left[\mathrm{Au}(\mathrm{IPr})\left(\mathrm{CH}_{2} \mathrm{COCH}_{3}\right)\right]$ and $\mathrm{KCl}$. This hypothesis was supported by the identification of 4-hydroxy-4-methyl-2-pentanone in the reaction mixture, the result of the base promoted aldol condensation of acetone. ${ }^{[35]}$ Furthermore, it should be noted that the formation of $\mathbf{2 a}$ was not observed when $\mathrm{NEt}_{3}$ was used as base, suggesting that the precipitation of $\mathrm{KCl}$ is the driving force of the reaction.

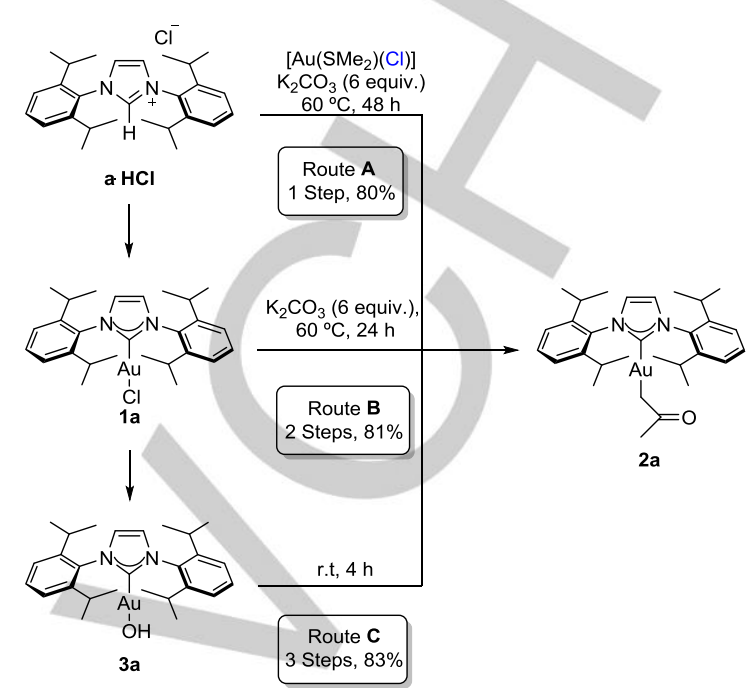

Scheme 3. Synthetic routes to $\mathbf{2 a}$. Total number of steps from $\mathbf{a} \cdot \mathbf{H C l}$ and overall yield are reported.

In route $\mathbf{C},[\mathrm{Au}(\mathrm{IPr})(\mathrm{OH})]$, which contains an internal base, is able to deprotonate acetone, affording $2 a$ and releasing water as a side-product. The ability of $\mathbf{3} \mathbf{a}$ to deprotonate substrates with $\mathrm{pK}_{\mathrm{a}}<31$ has been previously reported. ${ }^{[10]}$

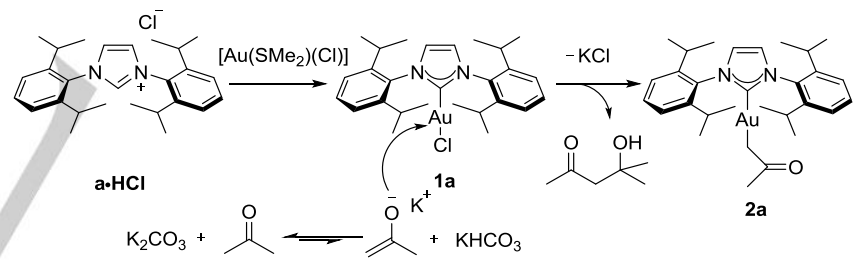

Scheme 4. Proposed mechanism for the formation of $\mathbf{2 a}$ (route $\mathbf{A}$ and $\mathbf{B}$ ).

\section{Synthesis of $[\mathrm{Au}(\mathrm{NHC})($ acetonyl)] Derivatives}

The preparation of Au-acetonyl derivatives, bearing $\mathrm{NHC}$ ligands of different electronic and steric properties, was explored next (Table 1). To this end, route $\mathbf{B}$ (Scheme 3 ) appeared as the methodology of choice where the readily accessible and commercially available $[\mathrm{Au}(\mathrm{NHC})(\mathrm{Cl})]$ compounds were used as precursors. Following this route, the synthesis and isolation of $[\mathrm{Au}(\mathrm{NHC})(\mathrm{OH})]^{[34]}$ derivatives was not necessary, therefore reducing the number of synthetic steps in the process. In addition, the preparation of Au-acetonyl derivatives containing non-IPr based ligands was more accessible, as $[\mathrm{Au}(\mathrm{NHC})(\mathrm{Cl})]$ complexes are air and moisture stable, ${ }^{[7 \mathrm{c},}{ }^{12]}$ while the corresponding $[\mathrm{Au}(\mathrm{NHC})(\mathrm{OH})]$ compounds must be prepared and stored under strictly inert conditions. ${ }^{[36]}$ 
Table 1 Library of $\mathrm{Au}(\mathrm{NHC})$-acetonyl complexes prepared in this study

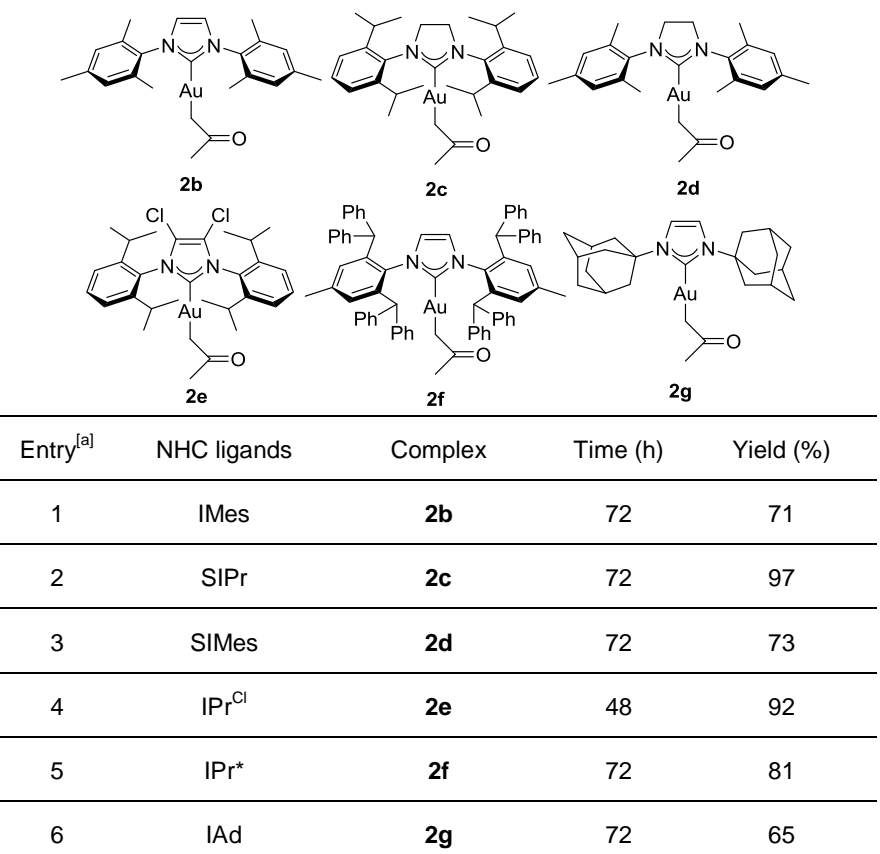

${ }^{\text {a }}$ Reaction conditions: route $\mathrm{B}_{2} \mathrm{CO}_{3}$ (6 equiv.), acetone, $60^{\circ} \mathrm{C}$.

Following route $\mathbf{B}$, the synthesis of $\left[\mathrm{Au}(\mathrm{NHC})\left(\mathrm{CH}_{2} \mathrm{COCH}_{3}\right)\right]$ derivatives bearing IMes (2b), SIPr (2c), SIMes (2d), IPr $\operatorname{Pr}^{\mathrm{C}[37]}$ (2e), $\quad \operatorname{IPr}^{*[38]}$ (2f) and $\mathrm{IAd}^{[39]}(\mathbf{2 g})$ was accomplished. All complexes were obtained in good to excellent yields, ranging from $65-97 \%$ (Table 1, entries 1-6) and fully characterized by NMR and IR spectroscopies and elemental analysis.

The most notable spectroscopic features of the [Au(NHC) $\left.\left(\mathrm{CH}_{2} \mathrm{COCH}_{3}\right)\right]$ complexes are summarized in Table 2. The ${ }^{1} \mathrm{H}$ NMR spectra of the complexes in $\mathrm{CDCl}_{3}$ showed two singlets corresponding to the $-\mathrm{CH}_{2}$ and $-\mathrm{CH}_{3}$ groups of the acetonyl moiety. In the case of complexes $\mathbf{2 a - 2 f}$, bearing $\mathrm{N}$-aryl substituted NHC ligands, these signals appeared in the range of 1.99-2.33 ppm for the $-\mathrm{CH}_{2}$ group, and 1.44-1.67 ppm for the $\mathrm{CH}_{3}$ group (Table 2, entries 1-6). These resonances appeared significantly shifted downfield in the case of $2 \mathrm{~g}$ (2.64 ppm for the $\mathrm{CH}_{2}$ group; $2.21 \mathrm{ppm}$ for $-\mathrm{CH}_{3}$ group), bearing an $\mathrm{N}$-alkyl $\mathrm{NHC}$ ligand, the most electron-donating of this series of $\mathrm{NHC}$ derivatives (Table 2, entry 7). ${ }^{[5 \mathrm{~d}]}$ The downfield region of the ${ }^{13} \mathrm{C}\left\{{ }^{1} \mathrm{H}\right\}$ NMR spectra of complexes $\mathbf{2 a - 2} \mathbf{g}$ showed the presence of two singlets. One of them corresponded to the carbenic carbon atom $(186.55-212.01 \mathrm{ppm})$ while the other was assigned to the carbon of the carbonyl group (212.12 - 212.50 ppm). ${ }^{[40]}$ All complexes were characterized by FTIR (ATR) spectroscopy. The most characteristic feature was the presence of strong adsorption bands at ca. $1650 \mathrm{~cm}^{-1}$ corresponding to the $\mathrm{C}=\mathrm{O}$ stretching frequency of the acetonyl moiety (Table 2$).{ }^{[28 c]}$
Table 2. NMR and IR spectroscopic data for $\mathbf{2 a - g}$

\begin{tabular}{cccccc}
\hline Entry & Complex & $\begin{array}{c}\delta\left(-\mathrm{CH}_{2}\right)^{[\mathrm{a}]} \\
(\mathrm{ppm})\end{array}$ & $\begin{array}{c}\delta\left(-\mathrm{CH}_{3}\right)^{[\mathrm{a}]} \\
(\mathrm{ppm})\end{array}$ & $\begin{array}{c}\delta\left(-\mathrm{C}_{\text {carb. }}\right)^{[\mathrm{b}]} \\
(\mathrm{ppm})\end{array}$ & $\begin{array}{c}v \mathrm{CO}^{[\mathrm{c}]} \\
\left(\mathrm{cm}^{-1}\right)\end{array}$ \\
\hline $\mathbf{2}$ & $\mathbf{2 a}$ & 2.06 & 1.53 & 193.06 & 1643 \\
\hline 3 & $\mathbf{2 b}$ & 2.10 & 1.64 & 191.31 & 1643 \\
\hline 4 & $\mathbf{2 c}$ & 1.99 & 1.44 & 212.01 & 1643 \\
\hline 5 & $\mathbf{2 d}$ & 2.02 & 1.54 & 211.58 & 1645 \\
\hline 6 & $\mathbf{2 e}$ & 2.06 & 1.52 & 193.01 & 1651 \\
\hline 7 & $\mathbf{2 g}$ & 2.33 & 1.67 & 192.61 & 1651 \\
\hline & $\mathbf{2 g}$ & 2.64 & 2.21 & 186.55 & 1643 \\
\hline
\end{tabular}

${ }^{\mathrm{a}}{ }^{1} \mathrm{H} \mathrm{NMR}\left(\mathrm{CDCl}_{3}\right) ;{ }^{\mathrm{b}}{ }^{13} \mathrm{C}\left\{{ }^{1} \mathrm{H}\right\}$ deptq NMR $\left(\mathrm{CDCl}_{3}\right) ;{ }^{\mathrm{c}} \mathrm{FTIR}(\mathrm{ATR})$.

The structures of complexes $2 \mathbf{2 a}-\mathbf{c}$ and $\mathbf{2 e - f}$ were unambiguously characterized by $\mathrm{X}$-ray diffraction analysis. Single crystals of the $\left[\mathrm{Au}(\mathrm{NHC})\left(\mathrm{CH}_{2} \mathrm{COCH}_{3}\right)\right]$ derivatives were grown by slow diffusion of pentane into saturated DCM or THF solutions. ${ }^{[41]}$ Figure 3 shows crystallographic representations of $2 \mathbf{2 a}-\mathbf{c}$ and $2 \mathbf{2 e - g}$. Unfortunately, several attempts to obtain suitable single crystals of $\mathbf{2 d}$ were unsuccessful. A summary of the most relevant crystallographic data for the different Au-acetonyl complexes is given in Table 3.

Table 3. Significant X-ray crystallographic data: angles (deg) and length $(\AA ̊)$

\begin{tabular}{|c|c|c|c|c|c|}
\hline Entry & Complex & $\begin{array}{c}\mathrm{C}_{\text {carb- }}-\mathrm{Au}-\mathrm{CH}_{2} \\
\text { (deg) }\end{array}$ & $\begin{array}{c}\mathrm{Au}-\mathrm{CH}_{2} \\
(\AA)\end{array}$ & $\begin{array}{c}\mathrm{CH}_{2}-\mathrm{CO} \\
(\AA)\end{array}$ & $\begin{array}{l}C=\mathrm{O} \\
(\AA)\end{array}$ \\
\hline 1 & $2 a$ & $175.7(3)^{\circ}$ & $2.091(9)$ & $1.456(12)$ & $1.230(11)$ \\
\hline $2^{\mathrm{a}}$ & $2 b$ & $\begin{array}{l}176.2(8)- \\
177.3(9)^{\circ}\end{array}$ & $\begin{array}{l}2.06(3)- \\
2.10(3)\end{array}$ & $\begin{array}{l}1.45(3)- \\
1.38(4)\end{array}$ & $\begin{array}{l}1.32(4)- \\
1.24(5)\end{array}$ \\
\hline $3^{a}$ & $2 c$ & $\begin{array}{l}174.4(4)- \\
179.4(4)^{\circ}\end{array}$ & $\begin{array}{l}2.054(10)- \\
2.111(12)\end{array}$ & $\begin{array}{l}1.445(16)- \\
1.531(18)\end{array}$ & $\begin{array}{c}1.18(3) \\
- \\
1.246(16)\end{array}$ \\
\hline 4 & $2 e$ & $176.3(3)^{\circ}$ & $2.222(9)$ & $1.497(16)$ & $1.230(19)$ \\
\hline $5^{\mathrm{a}}$ & $2 f$ & $\begin{array}{l}177.4(3)- \\
179.4(3)^{\circ}\end{array}$ & $2.096(9)$ & $\begin{array}{c}1.453(15)- \\
1.464(14)\end{array}$ & $\begin{array}{l}1.20(2)- \\
1.26(2)\end{array}$ \\
\hline 6 & $2 g$ & $178.62(17)^{\circ}$ & $2.083(5)$ & $1.467(6)$ & $1.227(6)$ \\
\hline
\end{tabular}

a Several molecules were found in the crystal lattice of these complexes: the range of distances and angles obtained is shown. 


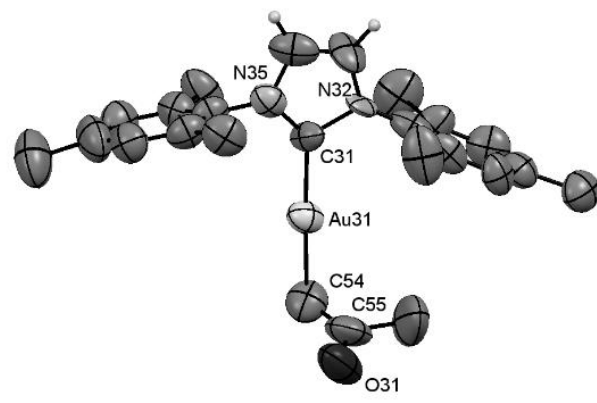

$2 b$

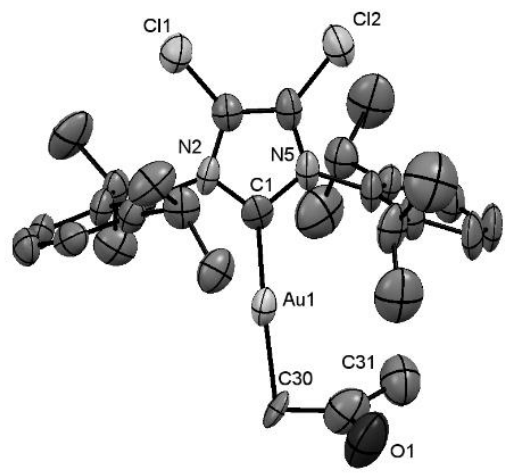

$2 \mathrm{e}$

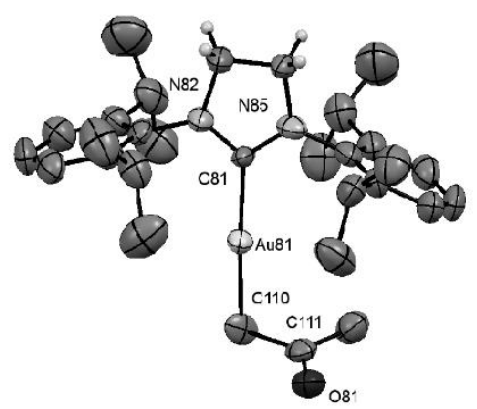

2c

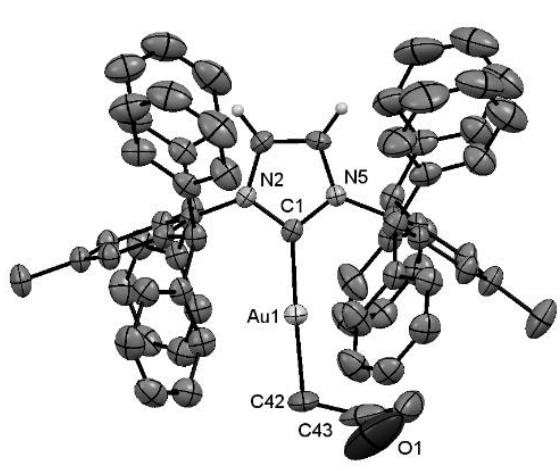

2f

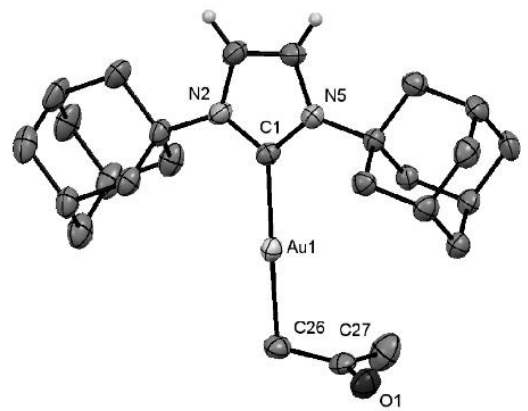

$2 \mathrm{~g}$

Figure 4. Thermal ellipsoid representation of $\mathbf{2 b}, \mathbf{c}$ and $\mathbf{2 e - g}$ showing $50 \%$ probability. Most of the $\mathrm{H}$ atoms were omitted for clarity. Two different molecules were found in the crystal lattice of $\mathbf{2} \mathbf{b}$ and $\mathbf{2} \mathbf{f}$; while $\mathbf{4}$ different conformers were found in $\mathbf{2} \mathbf{c}$. In these three cases, the thermal ellipsoid representation of one of the molecules is shown in the Figure. $\mathbf{2 f}$ presented a symmetry-induced disorder in the acetonyl region, due to a mismatch between the space group symmetry and the inherent symmetry of the complex.

\section{Stoichiometric Reactivity of [Au(NHC)(acetonyl)] Complexes}

The reactivity of $\mathbf{2 a}$ in term of its acid/base behavior was explored next. Protonolysis reactions of $\mathbf{2 a}$ with organic acids, of known $\mathrm{pK}_{\mathrm{a}}$ (DMSO) values, ${ }^{[42]}$ were performed to gauge its basicity. ${ }^{[10]}$ Thereby, free acetone would be released in the reaction medium and easily removed by evaporation.

Attempts to deprotonate $\mathrm{C}-\mathrm{H}$ bonds of fluoroarenes, such as pentafluorobenzene and 1,3,5-trifluorobenzene, $\left(\mathrm{pK}_{\mathrm{a}}(\mathrm{DMSO})=\right.$ 29-31.5), in toluene at $100^{\circ} \mathrm{C}$, to obtain $\left[\mathrm{Au}(\operatorname{IPr})\left(\mathrm{C}_{6} \mathrm{~F}_{n} \mathrm{H}_{5-n}\right)\right](\mathrm{n}=3$, $5)$ were unsuccessful. However, phenylacetylene $\left(\mathrm{pK}_{\mathrm{a}}\right.$ (DMSO) $=28.8$ ) reacted successfully with $2 a$ to give the corresponding complex $4 \mathbf{a}$, which was isolated in $87 \%$ yield after heating the mixture at $80^{\circ} \mathrm{C}$ for $24 \mathrm{~h}$ (Scheme 5 ).

With these results in hand, we tested other acidic species with lower $\mathrm{pK}_{\mathrm{a}}$ than phenylacetylene. $\mathbf{2 a}$ was reacted with phenol $\left(\mathrm{pK}_{\mathrm{a}}(\mathrm{DMSO})=18\right)$ at $80{ }^{\circ} \mathrm{C}$ to synthesize the corresponding gold(I)-phenolate 5 a derivative in $76 \%$ isolated yield. This reaction is an alternative protocol to the ones previously reported for the synthesis of gold-phenolates. ${ }^{[43]}$
Acetylacetone (acac- $\mathrm{H})$ and dimethoxy malonate, with $\mathrm{pK}_{\mathrm{a}}$ (DMSO) values $\sim 13-16$, reacted with $2 \mathbf{a}$ at $80^{\circ} \mathrm{C}$ to give $6 \mathbf{a}$ and 7 a respectively in good yields $\left(79-61 \%\right.$ isolated yields). ${ }^{[10]}$

Using more acidic substrates $\left(\mathrm{pK}_{\mathrm{a}}<10\right)$, a large number of organogold species were synthesized at room temperature. Indeed, 2a reacted with 4-mercaptopyridine, affording $\mathbf{8 a}$ in $\mathbf{8 8 \%}$ isolated yield. This product is particularly interesting, as gold complexes bearing a similar moiety have proven to present anticancer properties. ${ }^{[4]}$

Gold(I)-carboxylates, 9a-12a, were easily obtained in good yields $(72-88 \%)$ by treatment of $\mathbf{2 a}$ with the corresponding carboxylic acids; these compounds have been used as welldefined catalysts, and proposed as intermediates in carboxylation/decarboxylation reactions. ${ }^{[45]}$

Interestingly, 2a also provided access to the well-established catalyst $\left[\mathrm{Au}(\mathrm{IPr})\left(\mathrm{NTf}_{2}\right)\right]^{[46]}$ (13a) in good yield (89\%) using trifluoromethanesulfonic acid $\left(\mathrm{HNTf}_{2}\right)$.

Moreover, using an excess of pinacolborane, as a hydride source, $[\mathrm{Au}(\mathrm{IPr})(\mathrm{H})](\mathbf{1 4 a})$ was obtained in $80 \%$ yield. ${ }^{[9]}$ This reaction was carried out under argon atmosphere due to the high reactivity of $\mathbf{1 4 a}$. 
Furthermore, suitable crystals for X-ray diffraction analysis of the new complexes $\mathbf{6 a}, \mathbf{8} \mathbf{a}$ and $\mathbf{1 1} \mathbf{a}$ were obtained and their purity was confirmed by elemental analyses. ${ }^{[4]}$

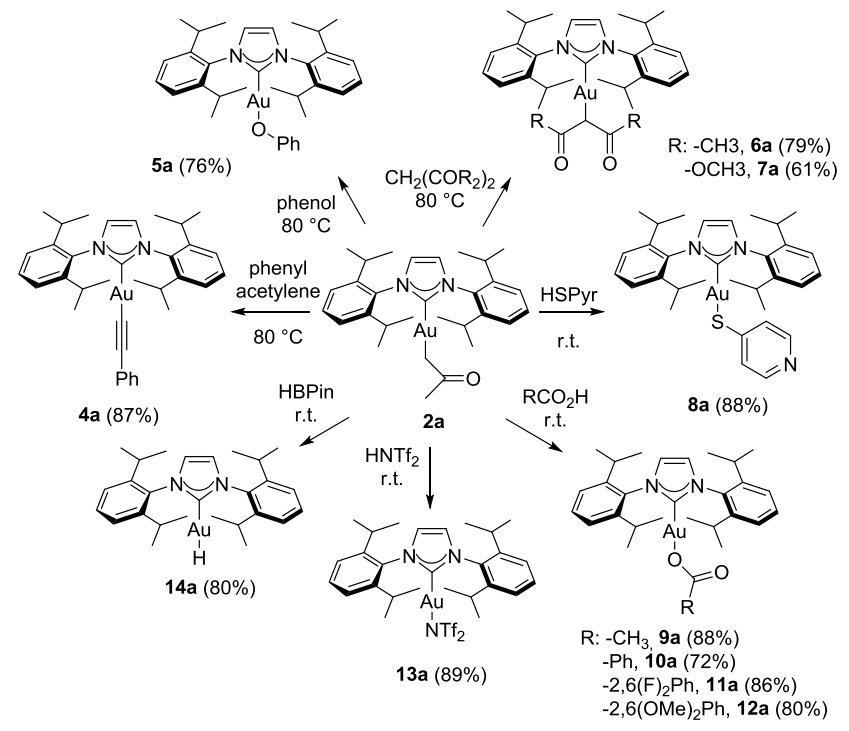

Scheme 5. Transformations involving 2a.

2a was reacted with $t-\mathrm{BuPh}_{2} \mathrm{SiCl}$, affording the stable complex 1a and the substituted silyloxy acetone, which were isolated in $99 \%$ and $72 \%$ yields, respectively (Scheme 6 ).

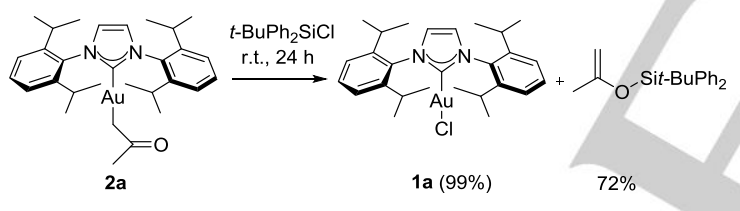

Scheme 6 . Reactivity of $2 \mathbf{a}$ with a substituted silane.

In view of this reactivity, $\left[\mathrm{Au}(\mathrm{IPr})\left(\mathrm{CH}_{2} \mathrm{COCH}_{3}\right)\right](\mathbf{2 a})$ emerged as a powerful precursor for several organogold compounds, as well as an attractive alternative to the well-known $[\mathrm{Au}(\mathrm{IPr})(\mathrm{Cl})]$ and $[\mathrm{Au}(\mathrm{IPr})(\mathrm{OH})]$ synthons. ${ }^{[10,12]}$

In this context, the [Au(IMes)(acetonyl)] (2b) complex was of particular interest as IMes is one of the most common NHCs in gold chemistry. However, its reactivity has been less developed compared to IPr, presumably because of the lower stability of $\mathrm{Au}$-IMes complexes. For example, while $[\mathrm{Au}(\mathrm{IPr})(\mathrm{OH})]$ can be prepared on a multi-gram scale and stored under air, the AuIMes hydroxide analogue is air and moisture sensitive. ${ }^{[36]}$ In contrast to $[\mathrm{Au}(\mathrm{IMes})(\mathrm{OH})]$, the $[\mathrm{Au}(\mathrm{IMes})$ (acetonyl)] derivative (2b) is a stable complex, easily synthesized using technical grade solvents and handled under non-inert conditions. For these reasons, we explored the synthetic potential of $\mathbf{2 b}$ (Scheme 7). ${ }^{[48]}$

The basicity of $\left[\mathrm{Au}(\mathrm{IMes})\left(\mathrm{CH}_{2} \mathrm{COCH}_{3}\right)\right]$ was evaluated by reacting it with different organic molecules bearing acidic protons; in contrast to $\mathbf{2 a}, \mathbf{2} \mathbf{b}$ did not react with phenylacetylene $\left(\mathrm{pK}_{\mathrm{a}}(\mathrm{DMSO})=28.8\right)$. This suggests that $\mathbf{2 b}$ is less basic than 2a. Therefore, more acidic substrates $\left(\mathrm{pK}_{\mathrm{a}}(\mathrm{DMSO})<28.8\right)$ were required to obtain organogold derivatives.

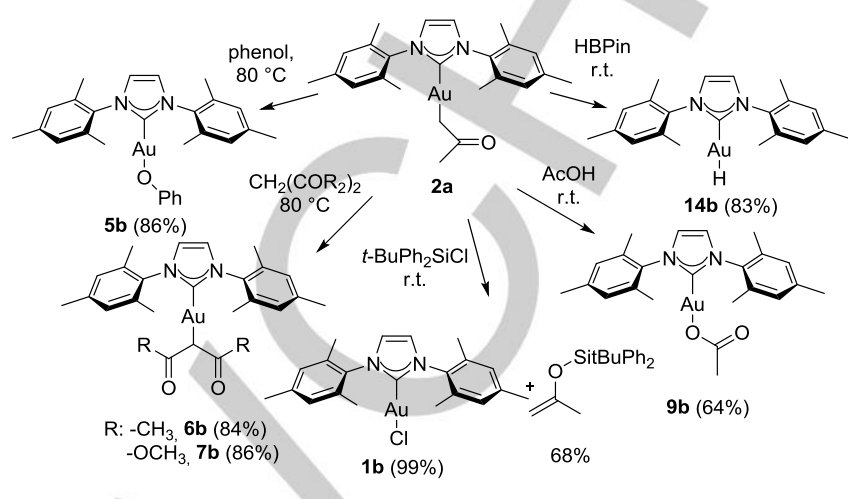

Scheme 7. Reactivity of $\mathbf{2 b}$

Indeed, $\mathbf{2 b}$ reacted with phenol, forming the corresponding goldphenolate complex (5b) in $86 \%$ yield. Reaction of $\mathbf{2 b}$ with acac$\mathrm{H}$ and dimethoxy malonate, at $80{ }^{\circ} \mathrm{C}$, afforded $\mathbf{6 b}$ and $\mathbf{7 b}$ in high yields ( $84 \%$ and $86 \%$ respectively). Furthermore, acetic acid was reacted with $\mathbf{2 b}$ to give $\mathbf{9 b}$ in $64 \%$ isolated yield.

Treatment of $\mathbf{2} \mathbf{b}$ with an excess of pinacol borane afforded $[\mathrm{Au}(\mathrm{IMes})(\mathrm{H})](\mathbf{1 4 b})$ which was isolated in high yield $(83 \%) .{ }^{[49]} \mathrm{As}$ is the case with $14 a$, this reaction required inert conditions to prevent decomposition of $\mathbf{1 4 b}$.

Finally, $\mathbf{2} \mathbf{b}$ reacted smoothly with $t-\mathrm{BuPh}_{2} \mathrm{SiCl}$, affording $\mathbf{1 b}$ and the corresponding substituted sylil enol ether. The former was isolated in $99 \%$ yield and the latter in $68 \%$.

Suitable crystals for X-ray diffraction analysis were obtained for the new complexes $\mathbf{5 b}, \mathbf{7 b}$ and $\mathbf{9 b}$, and elemental analyses confirmed their purities. ${ }^{[50]}$

The observed reactivity makes [Au(IMes)(acetonyl)] a convenient precursor to synthesize a number of Au-IMes derivatives, which will enable further development of this chemistry.

\section{Catalytic Reactivity of [Au(IPr)(acetonyl)] 2a}

To further test the applicability of $\mathrm{Au}(\mathrm{NHC})$-acetonyl complexes, we explored whether the newly synthesized derivatives could be used as precatalysts. As IPr is the most common NHC ligand in gold catalysis and its precursors are commercially available, we decided to use $\mathbf{2} \mathbf{a}$ as our reference catalyst.

We selected two well-defined gold(I)-catalyzed transformations: the hydration of alkynes to form ketones ${ }^{[51]}$ and the rearrangement of propargylic acetates to form substituted indenes. ${ }^{[52]}$ The active catalyst for these reactions is believed to be a $[\mathrm{Au}(\mathrm{NHC})]^{+}$species. We envisioned that this active catalyst could be formed in situ by reacting $\mathbf{2 a}$ with a protic acid. ${ }^{[1-52]}$ Therefore, the reactions can be performed without requiring the 
use of expensive and hygroscopic silver salts $\mathrm{AgX}(\mathrm{X}=\mathrm{OTf}$, $\left.\mathrm{BF}_{4}, \mathrm{SbF}_{6}, \mathrm{PF}_{6}\right),{ }^{[53]}$ which are known to be active catalysts in a number of transformations. ${ }^{[54]}$

Benchmark substrates, usually employed in the development of these transformations, were used in order to permit a better comparison with the previously reported protocols.

\section{Gold(I)-Catalyzed Alkyne Hydration to Ketones}

A number of gold complexes have been demonstrated to effectively catalyze the hydration of alkynes. ${ }^{[55]}$ In order to test the catalytic activity of $\mathbf{2 a}$ in this transformation, we studied the hydration of diphenylacetylene (Table 4).

Neither $\mathbf{2 a}$ nor $\mathrm{HBF}_{4} \cdot \mathrm{H}_{2} \mathrm{O}$ alone can catalyze the reaction (Table 4 , entry 1 and 2). However, in the presence of a $1: 1$ ratio of $2 a$ and $\mathrm{HBF}_{4} \cdot \mathrm{H}_{2} \mathrm{O}$, 1,2-diphenylethanone was obtained in $80 \%$ conversion after $2 \mathrm{~h}$ (Table 4, entry 3 ) and full conversion was reached after $4 \mathrm{~h}$ (Table 4 , entry 4 ). When 2 equiv. of acid were used with respect to $\mathbf{2 a}$, full conversion was obtained after $2 \mathrm{~h}$ (Table 4, entry 5). ${ }^{[51,55 \mathrm{~d}]}$ In agreement with previous findings using $\mathrm{Au}(\mathrm{I})-\mathrm{OH}$ as precatalyst, ${ }^{[55 \mathrm{~d}]}$ a slight excess of acid was necessary to ensure the complete conversion of the precatalyst into the active species.

Table 4 Hydration of alkynes

\begin{tabular}{|c|c|c|c|}
\hline Entry $^{[a]}$ & 2a: $\mathrm{HBF}_{4} \cdot \mathrm{H}_{2} \mathrm{O}$ & Time (h) & Conversion (\%) \\
\hline 1 & $1: 0$ & 2 & n.r. ${ }^{[c]}$ \\
\hline 2 & $0: 1$ & 2 & n.r. ${ }^{[\mathrm{c}]}$ \\
\hline 3 & $1: 1$ & 2 & $80^{[b]}$ \\
\hline 4 & $1: 1$ & 4 & $>99^{[b]}$ \\
\hline 5 & $1: 2$ & 2 & $>99^{[b]}$ \\
\hline
\end{tabular}

${ }^{a}$ Reaction conditions: diphenylacetylene (0.5 mmol), 1,4-dioxane/water (2:1, 1 $\mathrm{mL}) ;{ }^{\mathrm{b}} \mathrm{GC}$ conversions; ${ }^{\mathrm{c}}$ n.r. $=$ no reaction

\section{Gold(I)-catalyzed Synthesis of Substituted Indenes from Propargylic Acetates}

Cationic gold complexes have been shown to exhibit high catalytic activity in the intramolecular rearrangementhydroarylation of propargylic acetates, affording different products depending on reaction conditions. Under anhydrous conditions, alkyne activation could lead to migration of the acetate group, producing allenes. These compounds are believed to be intermediates in the synthesis of indenes. ${ }^{[52]}$ Whereas, in the presence of water the reaction produced conjugated enones. ${ }^{[56]}$ Therefore, the catalytic behavior of $2 \mathbf{a}$ was tested in this transformation, using $\mathrm{HBF}_{4} \cdot \mathrm{Et}_{2} \mathrm{O}$ to activate the Au-acetonyl derivative.

Reaction of propargylic acetate (15), in the presence of $2 \mathrm{a}$ and $\mathrm{HBF}_{4} \cdot \mathrm{Et}_{2} \mathrm{O}(1: 1.5)$, led to the formation of the allene (16) after 15 minutes (Table 5 , entry 1 ). Conversion into a mixture (40:60) of the kinetic (17) and the thermodynamic (18) indenes was observed by GC analysis of the reaction mixture after $24 \mathrm{~h}$ (Table 5, entry 2). Longer reaction times ( $48 \mathrm{~h}$ ) led to the exclusive formation of indene 18 (Table 5 , entry 3 ). 2a was found to be less active compared to the closely related $\mathrm{Au}(\mathrm{I})-\mathrm{OH}$ derivatives. ${ }^{[56 c]}$ However, the slower reactivity of the $\mathrm{Au}(\mathrm{I})$ acetonyl complex permitted the addition of an extra control element to this transformation and allowed us to selectively obtain allene $\mathbf{1 6}$ and the thermodynamic indene $\mathbf{1 8 .}$

Table 5. Transformation of propargylic acetates into substituted allenes and indenes

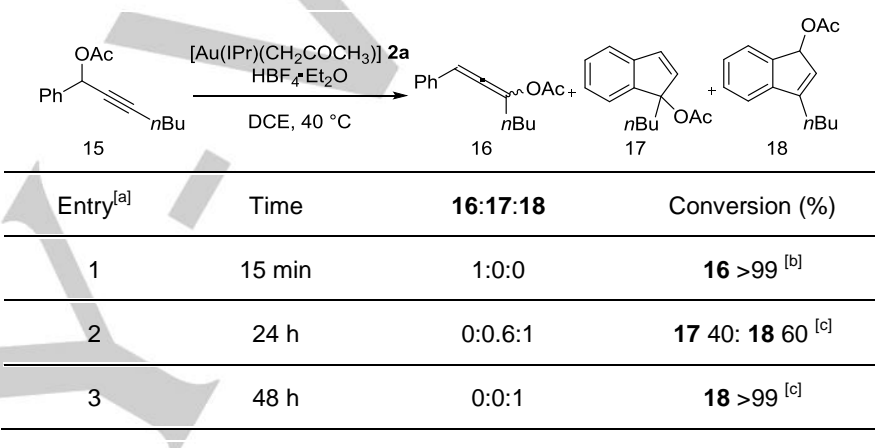

${ }^{\text {a }}$ Reaction conditions: propargylic alcohol $(0.5 \mathrm{mmol}), 2 \mathrm{a}(2 \mathrm{~mol} \%), \mathrm{HBF}_{4} \cdot \mathrm{Et}_{2} \mathrm{O}$ (3 mol\%), DCE (10 mL); ${ }^{b}$ Coversion was calculated by ${ }^{1} \mathrm{H}$ NMR using pivaladehyde as internal standard $(0.5 \mathrm{mmol}) .{ }^{\mathrm{C}}$ Conversions and ratio between 17 and 18 were determined by GC analysis and confirmed by ${ }^{1} \mathrm{H}$ NMR spectroscopy.

\section{Conclusions}

The serendipitous discovery of the first $\mathrm{Au}(\mathrm{I})-\mathrm{NHC}$ acetonyl complex is herein reported. This complex, first observed as a side-product, has been prepared by straightforward procedures from easily and commercially available precursors. A family of complexes has been synthesized. Their ease of preparation renders them attractive alternatives for the well-known $[\mathrm{Au}(\mathrm{NHC})(\mathrm{Cl})]$ or $[\mathrm{Au}(\mathrm{NHC})(\mathrm{OH})]$ complexes. Particular attention was focused on the complexes bearing the common $\mathrm{IPr}$ and IMes ligands where we have demonstrated that these species are versatile synthons, permitting access to a variety of organogold complexes. Our initial studies revealed that $\mathrm{Au}(\mathrm{IPr})$ acetonyl is a useful precatalyst. Further studies to investigate new reactivities and properties of these intriguing Au-acetonyl complexes are currently ongoing. 


\section{Experimental Section}

General considerations: Unless otherwise stated, all solvents and reagents were used as purchased and all reactions were performed under air. NMR spectra were recorded on 500 and $300 \mathrm{MHz}$ spectrometers at room temperature in $\mathrm{CDCl}_{3}$ or $\mathrm{C}_{6} \mathrm{D}_{6}$. Chemical shifts $(\delta)$ are reported in ppm, relative to the solvent residual peak $\mathrm{CDCl}_{3}(7.26$ ppm for ${ }^{1} \mathrm{H}$ and $77.16 \mathrm{ppm}$ for ${ }^{13} \mathrm{C}$ ) and $\mathrm{C}_{6} \mathrm{D}_{6}$ (7.16 ppm for ${ }^{1} \mathrm{H}$ and 128.06 ppm for ${ }^{13} \mathrm{C}$ ). Data for ${ }^{1} \mathrm{H}$ NMR are reported as follows: chemical shift, multiplicity $(\mathrm{s}=$ singlet, $\mathrm{d}=$ doublet, $\mathrm{t}=$ triplet, $\mathrm{br}=$ broad signal, $\mathrm{m}=$ multiplet), coupling constants $(\mathcal{J})$ in $\mathrm{Hz}$ and integration. For the assignment of the ${ }^{1} \mathrm{H}$ and ${ }^{13} \mathrm{C}\left\{{ }^{1} \mathrm{H}\right\}$ deptq NMR spectra of gold complexes COSY, HSQC and HMBC experiments were also performed. Elemental analyses were carried out by the analytical services of London Metropolitan University. Crystals were grown by slow diffusion of pentane into a saturated $\mathrm{DCM} / \mathrm{THF} / \mathrm{CDCl}_{3}$ solution. FTIR (ATR) spectra were recorded on a Shimadzu spectrophotometer. For full experimental data of all compounds, see supporting information.

Preparation of $\left[\mathrm{Au}(\mathrm{NHC})\left(\mathrm{CH}_{2} \mathrm{COCH}_{3}\right)\right](2 \mathrm{a}-\mathrm{b})$, route A Scheme 3: A mixture of $\mathrm{NHC} \cdot \mathrm{HCl}$ (1 equiv.), $\left[\mathrm{Au}\left(\mathrm{SMe}_{2}\right)(\mathrm{Cl})\right]$ (1 equiv.) and $\mathrm{K}_{2} \mathrm{CO}_{3}(6$ equiv.) in acetone (2-3 mL) was stirred for $48-72 \mathrm{~h}$ at $60^{\circ} \mathrm{C}$. The solution was then filtered through a pad of Celite $\AA$, the solvent removed under vacuum. The resulting solid was dissolved in the minimum amount of $\mathrm{CH}_{2} \mathrm{Cl}_{2}(2-3 \mathrm{~mL})$ and precipitated by addition of pentane (ca. $\left.10 \mathrm{~mL}\right)$. The precipitate was collected by filtration, washed with pentane $(3 \times 2 \mathrm{~mL})$ and dried under vacuum, affording the corresponding $\left[\mathrm{Au}(\mathrm{NHC})\left(\mathrm{CH}_{2} \mathrm{COCH}_{3}\right)\right]$ as a microcrystalline white solid.

Preparation of $\left[\mathrm{Au}(\mathrm{NHC})\left(\mathrm{CH}_{2} \mathrm{COCH}_{3}\right)\right](2 \mathrm{a}-\mathrm{g})$, route B Scheme 3: A mixture of $[\mathrm{Au}(\mathrm{NHC})(\mathrm{Cl})]$ (1 equiv.) and $\mathrm{K}_{2} \mathrm{CO}_{3}$ (6 equiv.) in acetone (2 $\mathrm{mL}$ ) was stirred at $60{ }^{\circ} \mathrm{C}$ for $24-72 \mathrm{~h}$. The solution was then filtered through a pad of $\mathrm{Celite} \AA$, the solvent removed under vacuum. The resulting solid was dissolved in the minimum amount of $\mathrm{CH}_{2} \mathrm{Cl}_{2}(2-3 \mathrm{~mL})$ and precipitated by addition of pentane $(c a .10 \mathrm{~mL})$. The precipitate was collected by filtration, washed with pentane $(3 \times 5 \mathrm{~mL})$ and dried under vacuum, affording the corresponding $\left[\mathrm{Au}(\mathrm{NHC})\left(\mathrm{CH}_{2} \mathrm{COCH}_{3}\right)\right]$ as a microcrystalline white solid.

Preparation of $\left[\mathrm{Au}(\mathrm{IPr})\left(\mathrm{CH}_{2} \mathrm{COCH}_{3}\right)\right]$ (2a), route C Scheme 3: $[\mathrm{Au}(\mathrm{IPr})(\mathrm{OH})](400 \mathrm{mg}, 0.66 \mathrm{mmol}, 1$ equiv.) was dissolved in acetone (5 $\mathrm{mL}$ ) and stirred for $4 \mathrm{~h}$ at room temperature. The solvent was then removed under vacuum. The resulting solid was dissolved in the minimum amount of $\mathrm{CH}_{2} \mathrm{Cl}_{2}(2-3 \mathrm{~mL})$ and precipitated by addition of pentane (ca. $10 \mathrm{~mL}$ ). The precipitate was collected by filtration, washed with pentane $(3 \times 5 \mathrm{~mL})$ and dried under vacuum, affording the corresponding $\left[\mathrm{Au}(\mathrm{IPr})\left(\mathrm{CH}_{2} \mathrm{COCH}_{3}\right)\right]$ as a microcrystalline white solid in $90 \%$ yield.

[Au(IPr) $\left(\mathrm{CH}_{2} \mathrm{COCH}_{3}\right)$ ] (1,3-bis(2,6-di isopropylphenyl)-2,3-dihydro-1Himidazol-2-yl)(2-oxopropyl)gold (2a): Complex 2a was synthesized following route $\mathbf{A}$ using $\mathrm{IPr} \cdot \mathrm{HCl}(800 \mathrm{mg}, 1.82 \mathrm{mmol}, 1$ equiv.), $\left[\mathrm{Au}\left(\mathrm{SMe}_{2}\right)(\mathrm{Cl})\right](554.37 \mathrm{mg}, 1.82 \mathrm{mmol}, 1$ equiv. $), \mathrm{K}_{2} \mathrm{CO}_{3}(1.51 \mathrm{~g}, 10.92$ mmol, 6 equiv.) in acetone $(10 \mathrm{~mL})$. The reaction was stirred for $48 \mathrm{~h}$ at $60{ }^{\circ} \mathrm{C}$. The desired product was obtained as a white solid in $80 \%$ yield (968.52 mg, $1.51 \mathrm{mmol})$. Complex 2a was also synthesized following route $\mathrm{B}$ using $[\mathrm{Au}(\mathrm{IPr})(\mathrm{Cl})]\left(200 \mathrm{mg}, 1.82 \mathrm{mmol}, 1\right.$ equiv.) and $\mathrm{K}_{2} \mathrm{CO}_{3}$ (1.51 g, $10.92 \mathrm{mmol}, 6$ equiv.) in acetone $(5 \mathrm{~mL})$. The reaction was stirred for $24 \mathrm{~h}$ at $60{ }^{\circ} \mathrm{C}$. The desired product was obtained as a white solid in $84 \%$ yield $(173.82 \mathrm{mg}, 0.32 \mathrm{mmol}) .{ }^{1} \mathrm{H} \mathrm{NMR}\left(500 \mathrm{MHz}, \mathrm{CDCl}_{3}\right)$ : $\delta$ $=7.49(\mathrm{t}, J=7.8 \mathrm{~Hz}, 2 \mathrm{H}, \mathrm{CH}$ aromatic $\mathrm{IPr}), 7.28(\mathrm{~d}, J=7.8 \mathrm{~Hz}, 4 \mathrm{H}, \mathrm{CH}$ aromatic IPr), 7.13 (s, 2H, CH imidazole IPr), 2.56 (sept, $J=6.9 \mathrm{~Hz}, 4 \mathrm{H}$, $\left.\mathrm{CH}\left(\mathrm{CH}_{3}\right)_{2}\right), 2.06\left(\mathrm{~s}, 2 \mathrm{H}, \mathrm{CH}_{2}\right), 1.53\left(\mathrm{~s}, 3 \mathrm{H}, \mathrm{CH}_{3}\right), 1.32$ (d, J = $6.9 \mathrm{~Hz}$, $\left.12 \mathrm{H}, \mathrm{CH}\left(\mathrm{CH}_{3}\right)_{2}\right), 1.21\left(\mathrm{~d}, J=6.9 \mathrm{~Hz}, 12 \mathrm{H}, \mathrm{CH}\left(\mathrm{CH}_{3}\right)_{2}\right) ;{ }^{13} \mathrm{C}\left\{{ }^{1} \mathrm{H}\right\} \mathrm{NMR}(126$ $\left.\mathrm{MHz}, \mathrm{CDCl}_{3}\right): \delta=212.12(\mathrm{C}=\mathrm{O}), 193.06(\mathrm{C}$ carbene $), 145.83(\mathrm{CH}$ aromatic IPr), $134.42(\mathrm{CH}$ aromatic $\mathrm{IPr}), 130.47(\mathrm{CH}$ aromatic $\mathrm{IPr})$, $124.41(\mathrm{CH}$ aromatic $\mathrm{IPr}), 124.15(\mathrm{CH}$ aromatic $\mathrm{IPr}), 122.81(\mathrm{CH}$ imidazole IPr), $40.71\left(\mathrm{CH}_{2}\right), 29.54\left(\mathrm{CH}_{3}\right), 28.88\left(\underline{\mathrm{CH}}\left(\mathrm{CH}_{3}\right)_{2}\right), 24.53$ $\left(\mathrm{CH}\left(\underline{\mathrm{CH}}_{3}\right)_{2}\right), 24.11\left(\mathrm{CH}\left(\underline{\mathrm{CH}}_{3}\right)_{2}\right)$; elemental analysis calcd $(\%): \mathrm{C} 55.98 \mathrm{H}$ 6.58, N 4.35; found: C 55.97, H 6.38, N 4.37; FTIR (ATR) v=1643 (C=O) $\mathrm{cm}^{-1}$.

[Au(IMes) $\left.\left(\mathrm{CH}_{2} \mathrm{COCH}_{3}\right)\right]$ (1,3-dimesityl-2,3-dihydro-1H-imidazol-2yl)(2-oxopropyl)gold (2b): Complex $\mathbf{2 b}$ was synthesized following using IMes. $\mathrm{HCl}(800 \mathrm{mg}, 2.34 \mathrm{mmol}, 1$ equiv.), [Au(SMe 2$)(\mathrm{Cl})](172.8 \mathrm{mg}, 0.58$ mmol, 1 equiv.), $\mathrm{K}_{2} \mathrm{CO}_{3}(1.95 \mathrm{~g}, 3.52 \mathrm{mmol}, 6$ equiv.) in acetone $(10 \mathrm{~mL})$ The reaction was stirred for $72 \mathrm{~h}$ at $60{ }^{\circ} \mathrm{C}$. The desired product was obtained as a white solid in $68 \%$ yield $(891.31 \mathrm{mg}, 1.59 \mathrm{mmol})$. Complex $\mathbf{2 b}$ was also synthesized following route $\mathbf{B}$ using $[\mathrm{Au}(\mathrm{IMes})(\mathrm{Cl})](200 \mathrm{mg}$, 0.373 mmol, 1 equiv.) and $\mathrm{K}_{2} \mathrm{CO}_{3}$ (g, 3.52 mmol, 6 equiv.) in acetone (2 $\mathrm{mL})$. The reaction was stirred for $72 \mathrm{~h}$ at $60^{\circ} \mathrm{C}$. The desired product was obtained as a white solid in $73 \%$ yield $(151.62 \mathrm{mg}, 0.27 \mathrm{mmol}) .{ }^{1} \mathrm{H}$ NMR $\left(500 \mathrm{MHz}, \mathrm{CDCl}_{3}\right): \delta=7.04(\mathrm{~s}, 2 \mathrm{H}, \mathrm{CH}$ imidazole IMes), $7.00(\mathrm{~s}, 4 \mathrm{H}, \mathrm{CH}$ aromatic IMes), 2.34 (s, 6H, $\mathrm{CH}_{3}$ p-phenyl IMes), $2.10\left(\mathrm{~s}, 12 \mathrm{H}, \mathrm{CH}_{3}\right.$ IMes), 2.09 (s, 3H, CH $) 1.64\left(\mathrm{~s}, 3 \mathrm{H}, \mathrm{CH}_{3}\right) \cdot{ }^{13} \mathrm{C}\left\{{ }^{1} \mathrm{H}\right\} \mathrm{NMR}(126 \mathrm{MHz}$, $\left.\mathrm{CDCl}_{3}\right): \delta=212.50(\mathrm{C}=\mathrm{O}), 191.31$ (C carbene), $139.47(\mathrm{CH}$ aromatic IMes), 134.92 ( $\mathrm{CH}$ aromatic IMes), 129.34 ( $\mathrm{CH}$ aromatic IMes), 41.13 $\left(\mathrm{CH}_{2}\right), 29.44\left(\mathrm{CH}_{3}\right), 21.26\left(\mathrm{CH}_{3}\right.$ p-phenyl IMes $), 17.99\left(\mathrm{CH}_{3}\right.$ aromatic IMes); elemental analysis calcd (\%): C 51.60, H 5.16, N 5.16; found: C 51.62, H 5.23, N 5.02; FTIR (ATR) $v=1643(\mathrm{C}=\mathrm{O}), \mathrm{cm}^{-1}$.

[Au(SIPr) $\left(\mathrm{CH}_{2} \mathrm{COCH}_{3}\right)$ ] 1,3-bis(2,6-di isopropylphenyl)imidazolidin-2yl)(2-oxopropyl)gold (2c): Complex $2 \mathrm{c}$ was synthesized following route B using $[\mathrm{Au}(\mathrm{SIPr})(\mathrm{Cl})]\left(100 \mathrm{mg}, 0.16 \mathrm{mmol}, 1\right.$ equiv.) and $\mathrm{K}_{2} \mathrm{CO}_{3}(138.88$ $\mathrm{mg}, 3.52 \mathrm{mmol}, 6$ equiv.) in acetone $(2 \mathrm{~mL})$. The reaction was stirred for $72 \mathrm{~h}$ at $60{ }^{\circ} \mathrm{C}$. The desired product was obtained as a white solid in $97 \%$ yield $(100 \mathrm{mg}, 0.156 \mathrm{mmol}) .{ }^{1} \mathrm{H}$ NMR $\left(300 \mathrm{MHz} \mathrm{CDCl}_{3}\right) \delta=7.40$ (dd, $J=$ $8.3 \mathrm{~Hz}, 7.2 \mathrm{~Hz}, 2 \mathrm{H}, \mathrm{CH}$ aromatic SIPr), $7.23(\mathrm{~d}, J=7.7 \mathrm{~Hz}, 4 \mathrm{H}, \mathrm{CH}$ aromatic SIPr), 4.00 (s, 4H, CH imidazole SIPr), 3.06 (sept, $J=6.9 \mathrm{~Hz}$, $\left.4 \mathrm{H}, \mathrm{C} \underline{\mathrm{H}}\left(\mathrm{CH}_{3}\right)_{2}\right), 1.99$ (q, J = $\left.0.9 \mathrm{~Hz}, 2 \mathrm{H}, \mathrm{CH}_{2}\right), 1.44(\mathrm{~d}, J=0.9 \mathrm{~Hz}, 12 \mathrm{H}$, $\mathrm{CH}_{3}$ ), 1.39 (d, $\left.J=6.8 \mathrm{~Hz}, 12 \mathrm{H}, \mathrm{CH}\left(\mathrm{CH}_{3}\right)_{2}\right), 1.33(\mathrm{~d}, J=7.0 \mathrm{~Hz}, 12 \mathrm{H}$, $\left.\mathrm{CH}\left(\mathrm{CH}_{3}\right)_{2}\right) ;{ }^{13} \mathrm{C}\left\{{ }^{1} \mathrm{H}\right\}$ NMR $\left(126 \mathrm{MHz}, \mathrm{CDCl}_{3}\right): \delta=212.39(\mathrm{C}=\mathrm{O}), 212.01$ (C carbene), 146.83 ( $\mathrm{CH}$ aromatic SIPr), 134.49 ( $\mathrm{CH}$ aromatic SIPr), $129.75\left(\mathrm{CH}\right.$ aromatic SIPr), $124.50\left(\mathrm{CH}\right.$ aromatic SIPr), $53.72\left(\mathrm{CH}_{2}\right.$ imidazole SIPr), $41.00\left(\mathrm{CH}_{2}\right), 29.42\left(\mathrm{CH}\left(\mathrm{CH}_{3}\right)_{2}\right), 29.06\left(\mathrm{CH}_{3}\right), 25.11$ $\left(\mathrm{CH}_{3}\right), 24.25\left(\mathrm{CH}_{3}\right)$; elemental analysis calcd (\%): $\mathrm{C} 55.88, \mathrm{H} 6.79, \mathrm{~N}$ 4.42; found: C 55.90, H 6.72, N 4.35; FTIR (ATR) $v=1643(\mathrm{C}=\mathrm{O}) \mathrm{cm}^{-1}$.

[Au(SIMes) $\left.\left(\mathrm{CH}_{2} \mathrm{COCH}_{3}\right)\right]$

1,3-dimesitylimidazolidin-2-yl)(2oxopropyl)gold (2d): Complex $\mathbf{2 d}$ was synthesized following route $\mathbf{B}$ using [Au(SIMes)(Cl)] (100 mg, 0.58 mmol, 1 equiv.) and $\mathrm{K}_{2} \mathrm{CO}_{3}$ (486.51 $\mathrm{mg}, 3.52 \mathrm{mmol}, 6$ equiv.) in acetone $(2 \mathrm{~mL})$. The reaction was stirred for $72 \mathrm{~h}$ at $60{ }^{\circ} \mathrm{C}$. The desired product was obtained as a white solid in $73 \%$ yield $(75.76 \mathrm{mg}, 0.13 \mathrm{mmol}) .{ }^{1} \mathrm{H}$ NMR $\left(400 \mathrm{MHz} \mathrm{CDCl}_{3}\right): \delta=6.95(\mathrm{~s}, 4 \mathrm{H}$, $\mathrm{CH}$ aromatic SIMes), 3.92 (s, 4H, $\mathrm{CH}_{2}$ imidazole SIMes), 2.31 (s, 12H, $\mathrm{CH}_{3}$ aromatic SIMes), 2.29 (s, $6 \mathrm{H}, \mathrm{CH}_{3}$ p-phenyl SIMes), $2.02(\mathrm{~d}, J=0.8$ $\left.\mathrm{Hz}, 2 \mathrm{H}, \mathrm{CH}_{2}\right), 1.54$ (s, 3H, $\left.\mathrm{CH}_{3}\right) .{ }^{13} \mathrm{C}\left\{{ }^{1} \mathrm{H}\right\} \mathrm{NMR}\left(101 \mathrm{MHz}, \mathrm{CDCl}_{3}\right): \delta=$ $212.49(\mathrm{C}=\mathrm{O}), 211.58$ (C carbene), 138.66 ( $\mathrm{CH}$ aromatic SIMes), 135.81 (CH aromatic SIMes), 135.09 ( $\mathrm{CH}$ aromatic SIMes), 129.61 ( $\mathrm{CH}$ aromatic SIMes), $50.86\left(\mathrm{CH}_{2}\right.$ imidazole SIMes), $41.41\left(\mathrm{CH}_{2}\right), 29.30\left(\mathrm{CH}_{3}\right), 21.18$ $\left(\mathrm{CH}_{3}\right.$ p-phenyl SIMes), $18.17\left(\mathrm{CH}_{3}\right.$ aromatic SIMes); elemental analysis calcd (\%): C 51.43, H 5.58, N 5.00; found: C 51.35, H 5.71, N 4.97; FTIR (ATR) $v=1645(\mathrm{C}=\mathrm{O}) \mathrm{cm}^{-1}$

$\left[\mathrm{Au}\left(\mathrm{IPr}^{\mathrm{Cl}}\right)\left(\mathrm{CH}_{2} \mathrm{COCH}_{3}\right)\right]$ 4,5-dichloro-1,3-bis(2,6-diisopropylphenyl)2,3-dihydro-1H-imidazol-2-yl)(2-oxopropyl)gold (2e): Complex 2e was synthesized following route $\mathrm{B}$ using $\left[\mathrm{Au}\left(\mathrm{IPr}^{\mathrm{Cl}}\right)(\mathrm{Cl})\right](100 \mathrm{mg}, 0.145 \mathrm{mmol}$, 
1 equiv.) and $\mathrm{K}_{2} \mathrm{CO}_{3}$ (120.2 mg, $0.870 \mathrm{mmol}, 6$ equiv.) in acetone ( $2 \mathrm{~mL}$ ) The reaction was stirred for $48 \mathrm{~h}$ at $60{ }^{\circ} \mathrm{C}$. The desired product was obtained as a white solid in $81 \%$ yield $(83.17 \mathrm{mg}, 0.117 \mathrm{mmol}){ }^{1} \mathrm{H}$ NMR $\left(500 \mathrm{MHz}_{\mathrm{CDCl}}\right): \delta=7.54\left(\mathrm{t}, J=7.7 \mathrm{~Hz}, 2 \mathrm{H}, \mathrm{CH}\right.$ aromatic $\left.\mathrm{IPr}^{\mathrm{Cl}}\right), 7.31$ (d, $J=7.8 \mathrm{~Hz}, 4 \mathrm{H}, \mathrm{CH}$ aromatic $\mathrm{IPr}^{\mathrm{Cl}}$ ), 2.46 (2.45 (sept, J=6.8, 4H, $\left.\mathrm{CH}\left(\mathrm{CH}_{3}\right)_{2}\right), 2.06$ (s, 2H, CH$\left.{ }_{2}\right), 1.52\left(\mathrm{~s}, 3 \mathrm{H}, \mathrm{CH}_{3}\right), 1.32$ (d, J=6.8 Hz, $12 \mathrm{H}$, $\left.\mathrm{CH}\left(\mathrm{CH}_{3}\right)_{2}\right), 1.25\left(\mathrm{~d}, J=6.9 \mathrm{~Hz}, 12 \mathrm{H}, \mathrm{CH}\left(\mathrm{CH}_{3}\right)_{2}\right) .{ }^{13} \mathrm{C}\left\{{ }^{1} \mathrm{H}\right\} \mathrm{NMR}(126 \mathrm{MHz}$, $\left.\mathrm{CDCl}_{3}\right): \delta=212.13(\mathrm{C}=\mathrm{O}), 193.01$ (C carbene), $146.29(\mathrm{CH}$ aromatic $\left.\mathrm{IPr}^{\mathrm{Cl}}\right), 131.37\left(\mathrm{CH}\right.$ aromatic $\left.\mathrm{IPr}^{\mathrm{Cl}}\right), 124.47\left(\mathrm{CH}\right.$ aromatic $\left.\mathrm{IPr}^{\mathrm{Cl}}\right), 118.87$ $(\mathrm{CH}$ aromatic IPrCl$), 39.85\left(\mathrm{CH}_{2}\right), 29.56\left(\mathrm{CH}_{3}\right), 29.24\left(\mathrm{CH}\left(\mathrm{CH}_{3}\right)_{2}\right), 24.60$ $\left(\mathrm{CH}\left(\underline{\mathrm{CH}}_{3}\right)_{2}\right)$, $23.61\left(\mathrm{CH}\left(\underline{\mathrm{CH}}_{3}\right)_{2}\right)$; elemental analysis calcd (\%): $\mathrm{C} 50.64, \mathrm{H}$ 5.53, N 3.94; found: C 50.52, H 5.47, N 3.99; FTIR (ATR) $v=1651$ (C=O) $\mathrm{cm}^{-1}$.

[Au(IPr*) $\left.\left(\mathrm{CH}_{2} \mathrm{COCH}_{3}\right)\right]$ 1,3-bis(2,6-dibenzhydryl-4-methylphenyl)-2,3dihydro-1H-imidazol-2-yl)(2-oxopropyl)gold (2f): Complex $2 f$ was synthesized following route $\mathrm{B}$ using $\left[\mathrm{Au}\left(\mathrm{IPr}^{\star}\right)(\mathrm{Cl})\right](50 \mathrm{mg}, 0.044 \mathrm{mmol}, 1$ equiv.) and $\mathrm{K}_{2} \mathrm{CO}_{3}(36.2 \mathrm{mg}, 0.262 \mathrm{mmol}, 6$ equiv.) in acetone $(2 \mathrm{~mL})$. The reaction was stirred for $72 \mathrm{~h}$ at $60{ }^{\circ} \mathrm{C}$. The desired product was obtained as a white solid in $92 \%$ yield $(43.5 \mathrm{mg}, 0.037 \mathrm{mmol}) .{ }^{1} \mathrm{H}$ NMR $\left(500 \mathrm{MHz}, \mathrm{CDCl}_{3}\right): \delta=7.25-7.09\left(\mathrm{~m}, 26 \mathrm{H}, \mathrm{Ph}\right.$ groups $\left.\mathrm{IPr}^{\star}\right), 6.91-6.84$ $(\mathrm{m}, 14 \mathrm{H}), 5.77$ (s, 2H, CH imidazole $\left.\mathrm{IPr}^{\star}\right), 5.32\left(\mathrm{~s}, 4 \mathrm{H}, \mathrm{CH}(\mathrm{Ph})_{2}\right), 2.33$ (s, $\left.2 \mathrm{H}, \mathrm{CH}_{2}\right), 2.23\left(\mathrm{~s}, 6 \mathrm{H}, \mathrm{CH}_{3}\right.$ p-phenyl IPr $\left.{ }^{\star}\right), 1.67\left(\mathrm{~s}, 3 \mathrm{H}, \mathrm{CH}_{3}\right) \cdot{ }^{13} \mathrm{C}\left\{{ }^{1} \mathrm{H}\right\}$ NMR ( $\left.126 \mathrm{MHz} \mathrm{CDCl}_{3}\right): \delta=212.49(\mathrm{C}=\mathrm{O}), 192.61$ ( $\mathrm{C}$ carbene), 142.84 $\left(\mathrm{CH}\right.$ aromatic $\left.\mathrm{IPr}^{\star}\right), 141.09\left(\mathrm{CH}\right.$ aromatic $\left.\mathrm{IPr}^{\star}\right), 139.91(\mathrm{CH}$ aromatic $\left.\mathrm{IPr}^{\star}\right), 134.11\left(\mathrm{CH}\right.$ aromatic $\left.\mathrm{IPr}^{\star}\right), 130.13\left(\mathrm{CH}\right.$ aromatic $\left.\mathrm{IPr}^{\star}\right), 129.83(\mathrm{CH}$ aromatic $\left.\mathrm{IPr}^{*}\right), 129.46\left(\mathrm{CH}\right.$ aromatic $\left.\mathrm{IPr}^{\star}\right), 128.56\left(\mathrm{CH}\right.$ aromatic $\left.\mathrm{IPr}^{\star}\right)$, $128.45\left(\mathrm{CH}\right.$ aromatic $\left.\mathrm{IPr}^{\star}\right), 126.73\left(\mathrm{CH}\right.$ aromatic $\left.\mathrm{IPr}^{\star}\right), 126.71(\mathrm{CH}$ aromatic $\left.\mathrm{IPr}^{\star}\right), 123.09\left(\mathrm{CH}\right.$ imidazole $\left.\mathrm{IPr}^{\star}\right), 51.29\left(\mathrm{CH}(\mathrm{Ph})_{2}\right), 41.37\left(\mathrm{CH}_{2}\right)$, $29.89\left(\mathrm{CH}_{3}\right), 21.98\left(\mathrm{CH}_{3}\right.$ p-phenyl IPr $\left.{ }^{\star}\right)$; elemental analysis calcd $(\%)$ : C 74.09, H 5.27, N 2.40; found: C 73.97, H 5.22, N 2.47. FTIR (ATR) $v=$ $1651(\mathrm{C}=\mathrm{O}) \mathrm{cm}^{-1}$.

\section{[Au(IAd) $\left.\left(\mathrm{CH}_{2} \mathrm{COCH}_{3}\right)\right]$ 1,3-di(adamantan-1-yl)-2,3-dihydro-1H- imidazol-2-yl)(2-oxopropyl)gold (2g): Complex $\mathbf{2 g}$ was synthesized following route $B$ using $[\mathrm{Au}(\mathrm{IAd})(\mathrm{Cl})](50 \mathrm{mg}, 0.088 \mathrm{mmol}, 1$ equiv.) and $\mathrm{K}_{2} \mathrm{CO}_{3}$ (72.9 mg, 0.527 mmol, 6 equiv.) in acetone $(2 \mathrm{~mL})$. The reaction was stirred for $72 \mathrm{~h}$ at $60{ }^{\circ} \mathrm{C}$. The desired product was obtained as a white solid in $84 \%$ yield (43.26 mg, $0.073 \mathrm{mmol}) .{ }^{1} \mathrm{H} \mathrm{NMR}(300 \mathrm{MHz}$, $\mathrm{CDCl}_{3}$ ): $\delta=7.02\left(\mathrm{~s}, 2 \mathrm{H}, \mathrm{CH}\right.$ imidazole IAd), $2.64\left(\mathrm{~s}, 2 \mathrm{H}, \mathrm{CH}_{2}\right), 2.53(\mathrm{~d}, \mathrm{~J}$ $=3.0 \mathrm{~Hz}, 13 \mathrm{H}$. CH IAd), 2.25 (s, 6H, CH $\mathrm{CH}_{2} \mathrm{Ad}$ ), 2.21 (s, 3H, $\left.\mathrm{CH}_{3}\right), 1.76$ (d, $J=3.2 \mathrm{~Hz}, 14 \mathrm{H}, \mathrm{CH}$ IAd). ${ }^{13} \mathrm{C}\left\{{ }^{1} \mathrm{H}\right\} \mathrm{NMR}\left(126 \mathrm{MHz} \mathrm{CDCl}_{3}\right): \delta=213.09$ $(\mathrm{C}=\mathrm{O}), 186.55$ ( $\mathrm{C}$ carbene), 115.08 ( $\mathrm{CH}$ imidazole IAd), $58.89(\mathrm{CH} \mathrm{IAd})$, 44.38 ( CH IAd), 39.47 ( $\mathrm{CH} \mathrm{IAd),} 38.10\left(\mathrm{CH}_{2}\right), 36.04$ ( $\left.\mathrm{CH} \mathrm{IAd}\right), 30.06\left(\mathrm{CH}_{2}\right.$ IAd), $29.59\left(\mathrm{CH}_{3}\right)$; elemental analysis calcd (\%): C 52.88, H 6.32, N 4.74; found: C 52.78, H 6.27, N 4.63; FTIR (ATR) $v=1643(\mathrm{C}=\mathrm{O}) \mathrm{cm}^{-1}$.}

\section{Acknowledgements}

The ERC (Advanced Investigator Award-FUNCAT), EPSRC and Syngenta are gratefully acknowledged for support. Umicore AG is acknowledged for their generous gift of materials. S.P.N. is a Royal Society Wolfson Research Merit Award holder.

Keywords: gold • acetonyl - $N$-heterocyclic carbene • organogold complexes $\cdot$ catalysis
2008, 37, 1766-1775; d) Z. Li, C. Brouwer, C. He, Chem. Rev. 2008, 108, 3239-3265.

[2] a) A. S. K. Hashmi, Chem. Rev. 2007, 107, 3180-3211; b) O Debleds, E. Gayon, E. Vrancken, J.-M. Campagne, Beilstein J. Org. Chem. 2011, 7, 866-877; c) N. Marion, S. P. Nolan, Chem Soc. Rev. 2008, 37, 1776-1782; d) S. Freakley, Q. He, C. Kiely, G. Hutchings, Catal. Lett. 2014, 1-9.

[3] a) A. Vogler, H. Kunkely, Coord. Chem. Rev. 2001, 219-221, 489-507; b) G. C. Fortman, A. Poater, J. W. Levell, S. Gaillard, A. M. Z. Slawin, I. D. W. Samuel, L. Cavallo, S. P. Nolan, Dalton Trans. 2010, 39, 10382-10390; c) J. J. Hirner, Y. Shi, S. A. Blum, Acc. Chem. Res. 2011, 44, 603-613; d) R. Visbal, I. Ospino, J. M. López-de-Luzuriaga, A. Laguna, M. C. Gimeno, J. Am. Chem. Soc. 2013, 135, 4712-4715; e) E. E. LangdonJones, S. J. A. Pope, Chem. Commun. 2014, 50, 10343-10354; f) H. G. Raubenheimer, S. Cronje, Chem. Soc. Rev. 2008, 37, 1998-2011.

[4] D. J. Gorin, B. D. Sherry, F. D. Toste, Chem. Rev. 2008, 108, 3351-3378.

[5] a) R. H. Crabtree, J. Organomet. Chem. 2005, 690, 5451-5457; b) S. Díez-González, N. Marion, S. P. Nolan, Chem. Rev. 2009 109, 3612-3676; c) T. Dröge, F. Glorius, Angew. Chem., Int. Ed. 2010, 49, 6940-6952; Angew. Chem. 2010, 122, 7094-7107; d) D. J. Nelson, S. P. Nolan, Chem. Soc. Rev. 2013, 42, 6723-6753.

[6] J. Huang, E. D. Stevens, J. L. Petersen, S. P. Nolan, J. Am Chem. Soc. 1999, 121, 2674-2678.

[7] a) S. Gaillard, C. S. J. Cazin, S. P. Nolan, Acc. Chem. Res. 2011, 45, 778-787; b) S. P. Nolan, Acc. Chem. Res. 2010, 44, 91-100 c) P. de Frémont, N. M. Scott, E. D. Stevens, S. P. Nolan, Organometallics 2005, 24, 2411-2418; d) P. de Frémont, R. Singh, E. D. Stevens, J. L. Petersen, S. P. Nolan, Organometallics 2007, 26, 1376-1385.

[8] D. S. Laitar, P. Müller, T. G. Gray, J. P. Sadighi, Organometallics 2005, 24, 4503-4505.

[9] E. Y. Tsui, P. Müller, J. P. Sadighi, Angew. Chem., Int. Ed 2008, 47, 8937-8940; Angew. Chem. 2008, 120, 9069-9072.

[10] S. Gaillard, A. M. Z. Slawin, S. P. Nolan, Chem. Commun 2010, 46, 2742-2744

[11] A. Collado, A. Goméz-Suárez, Y. Oonishi, A. M. Z. Slawin, S. P. Nolan, Chem. Commun. 2013, 49, 10745-10747.

[12] A. Collado, A. Goméz-Suárez, A. R. Martin, A. M. Z. Slawin, S. P. Nolan, Chem. Commun. 2013, 49, 5541-5543.

[13] $\operatorname{IPr}=N, N^{\prime}$-bis(2,6-diisopropylphenyl)imidazol-2-ylidene;

[14] IMes $=N, N^{\prime}$-bis(2,4,6-trimethylphenyl)imidazol-2-ylidene;

[15] $\mathrm{SIPr}=N, N^{\prime}$-bis-(2,6-diisopropylphenyl)imidazolin-2-ylidene;

[16] SIMes $=N, N^{\prime}$-bis(2,4,6-trimethylphenyl)imidazolin-2-ylidene.

[17] a) D. Seebach, Angew. Chem., Int. Ed. Engl. 1988, 27, 1624 1654; Angew. Chem. 1988, 100, 1685-1715; b) L. R. Domingo, J. Andrés, in PATAI'S Chemistry of Functional Groups, John Wiley \& Sons, Ltd, 2009

[18] J. Vicente, A. Arcas, J. M. Fernández-Hernández, D. Bautista, Organometallics 2001, 20, 2767-2774.

[19] a) G. A. Slough, R. G. Bergman, C. H. Heathcock, J. Am. Chem Soc. 1989, 111, 938-949; b) D. A. Culkin, J. F. Hartwig, Acc Chem. Res. 2003, 36, 234-245; c) G. Chen, F. Y. Kwong, H. O Chan, W.-Y. Yu, A. S. C. Chan, Chem. Commun. 2006, 1413 1415; d) A. S. K. Hashmi, S. Schäfer, M. Wölfle, C. Diez Gil, P. Fischer, A. Laguna, M. C. Blanco, M. C. Gimeno, Angew Chem., Int. Ed. 2007, 46, 6184-6187; Angew. Chem. 2007, 119, 6297-6300; e) M. Henrion, M. J. Chetcuti, V. Ritleng, Chem. Commun. 2014, 50, 4624-4627.

[20] a) G. B. Shul'pin, G. V. Nizova, A. E. Shilov, J. Chem. Soc. Chem. Commun. 1983, 671-672; b) G. V. Nizova, M. V Serdobov, A. T. Nikitaev, G. B. Shul'pin, J. Organomet. Chem. 1984, 275, 139-144; c) J. Vicente, J. A. Abad, M.-T. Chicote, M.-D. Abrisqueta, J.-A. Lorca, M. C. Ramírez de Arellano, Organometallics 1998, 17, 1564-1568; d) K. Matsumoto, M. Ochiai, Coord. Chem. Rev. 2002, 231, 229-238; e) H.-W. F. Boke C. de Pater, K. Goubitz, J. Fraanje, P. H.M. Budzelaar, A W. Gal, K. Vrieze, Inorg. Chim. Acta 2005, 358, 431-436; f) M. 
Feller, A. Karton, G. Leitus, J. M. L. Martin, D. Milstein, J. Am. Chem. Soc. 2006, 128, 12400-12401; g) A. A. Vicente, J. M. Fernandez-Hernandez, Organometallics 2007, 6155-6169; h) J. Vicente, in PATAI'S Chemistry of Functional Groups, John Wiley \& Sons, Ltd, 2009.

[21] a) J. J. Doney, R. G. Bergman, C. H. Heathcock, J. Am. Chem Soc. 1985, 107, 3724-3726; b) T. Hirao, S. Nagata, Y. Yamana T. Agawa, Tetrahedron Lett. 1985, 26, 5061-5064; c) E. R. Burkhardt, J. J. Doney, R. G. Bergman, C. H. Heathcock, J. Am. Chem. Soc. 1987, 109, 2022-2039.

[22] D. Milstein, Acc. Chem. Res. 1984, 17, 221-226.

[23] a) J. Vicente, A. Arcas, J. M. Fernandez-Hernandez, A. Sironi, N. Masciocchi, Chem. Commun. 2005, 1267-1269; b) J. Vicente, A. Arcas, J. M. Fernández-Hernández, D. Bautista, Organometallics 2006, 25, 4404-4413.

[24] G. H. Posner, C. M. Lentz, J. Am. Chem. Soc. 1979, 101, 934946.

[25] a) D. P. Arnold, M. A. Bennett, J. Organomet. Chem. 1980, 199 119-135; b) B. J. Truscott, D. J. Nelson, C. Lujan, A. M. Z. Slawin, S. P. Nolan, Chem. Eur. J. 2013, 19, 7904-7916.

[26] M. A. Cairns, K. R. Dixon, M. A. R. Smith, J. Organomet. Chem. 1977, 135, C33-C34.

[27] a) C. R. Barone, S. de Pinto, L. Maresca, G. Natile, C. Pacifico, Inorg. Chim. Acta 2012, 383, 13-19; b) E. R. Burkhardt, R. G. Bergman, C. H. Heathcock, Organometallics 1990, 9, 30-44

[28] a) J. Vicente, M.-D. Bermudez, M.-T. Chicote, M.-J. SanchezSantano, J. Chem. Soc., Chem. Commun. 1989, 141-142; b) J. Vicente, M. D. Bermudez, J. Escribano, M. P. Carrillo, P. G. Jones, J. Chem. Soc., Dalton Trans. 1990, 3083-3089; c) J. Vicente, M.-D. Bermúdez, M.-P. Carrillo, P. G. Jones, J. Organomet. Chem. 1993, 456, 305-312.

a) M. A. Cinellu, A. Zucca, S. Stoccoro, G. Minghetti, M Manassero, M. Sansoni, J. Chem. Soc., Dalton Trans. 1996 4217-4225; b) F. Cocco, M. A. Cinellu, G. Minghetti, A. Zucca, S. Stoccoro, L. Maiore, M. Manassero, Organometallics 2010 , 29, 1064-1066.

[30] D. Fan, E. Meléndez, J. D. Ranford, P. F. Lee, J. J. Vittal, J. Organomet. Chem. 2004, 689, 2969-2974

[31] a) Y. Ito, M. Inouye, M. Suginome, M. Murakami, J. Organomet. Chem. 1988, 342, C41-C44; b) M. Murakami, M. Inouye, M. Suginome, Y. Ito, Bull. Chem. Soc. Jpn. 1988, 61, 3649-3652.

[32] a) L.G.Kuzmina, Koord.Khim. (Coord. Chem.) 1994, 20, 540546; b) F. Mohr, L. R. Falvello, M. Laguna, Eur. J. Inorg. Chem. 2006, 2006, 833-838.

[33] $\quad$ CCDC $=$ CCDC 1039059 (2a) contains the supplementary crystallographic data for this paper. These data can be obtained free of charge from The Cambridge Crystallographic Data Centre via www.ccdc.cam.ac.uk/data\%5Frequest/cif;

[34] F. Nahra, S. R. Patrick, A. Collado, S. P. Nolan, Polyhedron 2014, 84, 59-62.

[35] The 4-hydroxy-4-methyl-2-pentanone side-product can be easily removed from the mixture by washing with pentane;

[36] S. R. Patrick, A. Goméz-Suárez, A. M. Z. Slawin, S. P. Nolan, Organometallics 2013, 33, 421-424. $\mathrm{IPr}^{\mathrm{Cl}} \quad=\quad \mathrm{N}$, diisopropylphenyl)imidazol-2-ylidene;

[38] IPr* $=N, N^{\prime}$-1,3-bis(2,6-dibenzhydryl-4-methylphenyl)imidazol2-ylidene;

[39] IAd $=N, N^{\prime}$-diadamantylimidazol-2-ylidene;

[40] The assignements of the carbonyl groups of $\mathbf{2 a - g}$ were made through HSQC and HMBC experiments.

[41] $\quad \mathrm{CCDC}=\mathrm{CCDC} 1039060(\mathbf{2 b}), \mathrm{CCDC} 1039061$ (2c), CCDC 1039062 (2e), CCDC 1039063 (2f) and CCDC 1039064 (2g) contain the supplementary crystallographic data for this paper. These data can be obtained free of charge from The Cambridge Crystallographic Data Centre via www.ccdc.cam.ac.uk/data\%5Frequest/cif;
McCollum, N. R. Vanier, J. Am. Chem. Soc. 1975, 97, 70067014.

[43] a) J. D. Egbert, A. M. Z. Slawin, S. P. Nolan, Organometallics 2013, 32, 2271-2274; b) N. Ibrahim, M. H. Vilhelmsen, M. Pernpointner, F. Rominger, A. S. K. Hashmi, Organometallics 2013, 32, 2576-2583.

[44] a) M. V. Baker, P. J. Barnard, S. J. Berners-Price, S. K Brayshaw, J. L. Hickey, B. W. Skelton, A. H. White, J. Organomet. Chem. 2005, 690, 5625-5635; b) E. Schuh, C. Pflüger, A. Citta, A. Folda, M. P. Rigobello, A. Bindoli, A Casini, F. Mohr, J. Med. Chem. 2012, 55, 5518-5528.

[45] a) S. K. Schneider, W. A. Herrmann, E. Herdtweck, Z. Anorg Allg. Chem. 2003, 629, 2363-2370; b) S. Dupuy, F. Lazreg, A M. Z. Slawin, C. S. J. Cazin, S. P. Nolan, Chem. Commun. 2011, 47, 5455-5457; c) S. Dupuy, S. P. Nolan, Chem. Eur. J. 2013, 19, 14034-14038.

[46] L. Ricard, F. Gagosz, Organometallics 2007, 26, 4704-4707.

[47] $\quad \mathrm{CCDC}=\mathrm{CCDC} 1039066(\mathbf{6 a}), \mathrm{CCDC} 1039068(\mathbf{8 a})$ and CCDC 103970 (11a) contain the supplementary crystallographic data for this paper. These data can be obtained free of charge from The Cambridge Crystallographic Data Centre via www.ccdc.cam.ac.uk/data\%5Frequest/cif;

[48] 2b results more sensitive to acids, that has imposed some precautions in performing the reactions (see Supporting Information).

[49] H. Lv, J.-H. Zhan, Y.-B. Cai, Y. Yu, B. Wang, J.-L. Zhang, J. Am. Chem. Soc. 2012, 134, 16216-16227.

[50] $\quad \mathrm{CCDC}=\mathrm{CCDC} 1039065(\mathbf{5 b}), \mathrm{CCDC} 1039067(\mathbf{7 b})$ and CCDC 1039069 (9b) contain the supplementary crystallographic data for this paper. These data can be obtained free of charge from The Cambridge Crystallographic Data Centre via www.ccdc.cam.ac.uk/data\%5Frequest/cif;

[51] S. B. Gaillard, J.; Ramon, R.S.; Nun, P.; Slawin, A.M; Nolan, S.P., Chem. Eur. J. 2010, 16, 13729-13740.

[52] N. Marion, S. Díez-González, P. de Frémont, A. R. Noble, S. P. Nolan, Angew. Chem., Int. Ed. 2006, 45, 3647-3650; Angew. Chem. 2006, 118, 3729-3732.

[53] H. Schmidbaur, A. Schier, Z.Naturforsch. 2011, 66b, 329-350

[54] a) A. S. K. Hashmi, in Silver in Organic Chemistry, John Wiley \& Sons, Inc., 2010, pp. 357-379; b) X. Giner, C. Nájera, G. Kovács, A. Lledós, G. Ujaque, Adv. Synth. Catal. 2011, 353, 3451-3466; c) X. Giner, P. Trillo, C. Nájera, J. Organomet. Chem. 2011, 696, 357-361.

[55] For selected references see: a) E. Mizushima, K. Sato, T. Hayashi, M. Tanaka, Angew. Chem., Int. Ed. 2002, 41, 45634565; Angew. Chem. 2002, 114, 4745-4747; b) A. Leyva, A Corma, J. Org. Chem. 2009, 74, 2067-2074; c) N. Marion, R. S. Ramón, S. P. Nolan, J. Am. Chem. Soc. 2008, 131, 448-449; d) P. Nun, R. S. Ramón, S. Gaillard, S. P. Nolan, J. Organomet. Chem. 2011, 696, 7-11.

[56] a) N. Marion, P. Carlqvist, R. Gealageas, P. de Frémont, F. Maseras, S. P. Nolan, Chem. Eur. J. 2007, 13, 6437-6451; b) P. Nun, S. Gaillard, A. M. Z. Slawin, S. P. Nolan, Chem. Commun 2010, 46, 9113-9115; c) P. Nun, S. Gaillard, A. Poater, L. Cavallo, S. P. Nolan, Org. Biomol. Chem. 2011, 9, 101-104; d) A. Gómez-Suárez, R. S. Ramón, O. Songis, A. M. Z. Slawin, C. S. J. Cazin, S. P. Nolan, Organometallics 2011, 30, 5463-5470. 
Entry for the Table of Contents (Please choose one layout)

Layout 2:

\section{FULL PAPER}

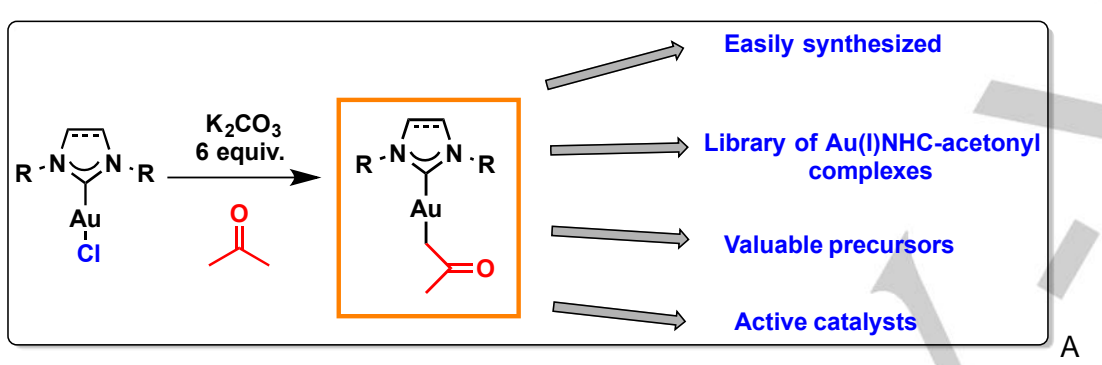

Danila Gasperini, ${ }^{a}$ Alba Collado, ${ }^{a}$ Adrián Goméz-Suárez, ${ }^{2}$ David B. Cordes, ${ }^{a}$ Alexandra M. Z. Slawin ${ }^{a}$ and Steven P. Nolan ${ }^{a, b^{*}}$

Page No. - Page No.

Au-acetonyl complexes: from sideproducts to valuable synthons

library of $[\mathrm{Au}(\mathrm{NHC})($ acetony I)] complexes has been easily synthesized. These complexes represent valuable synthetic precursors to a plethora of organogold species as well as active catalysts for gold(I)-catalyzed reactions. 